University of Louisville

ThinkIR: The University of Louisville's Institutional Repository

$12-2000$

\title{
A comparison of the characteristics of gardeners, their motivations for gardening and management practices of Blackacre Community Garden and Limerick Community Garden in Jefferson County, Kentucky.
}

Robin Oxnard Grossman 1974-

University of Louisville

Follow this and additional works at: https://ir.library.louisville.edu/etd

\section{Recommended Citation}

Grossman, Robin Oxnard 1974-, "A comparison of the characteristics of gardeners, their motivations for gardening and management practices of Blackacre Community Garden and Limerick Community Garden in Jefferson County, Kentucky." (2000). Electronic Theses and Dissertations. Paper 540.

https://doi.org/10.18297/etd/540

This Master's Thesis is brought to you for free and open access by ThinkIR: The University of Louisville's Institutional Repository. It has been accepted for inclusion in Electronic Theses and Dissertations by an authorized administrator of ThinkIR: The University of Louisville's Institutional Repository. This title appears here courtesy of the author, who has retained all other copyrights. For more information, please contact thinkir@louisville.edu. 


\title{
A COMPARISON OF THE CHARACTERISTICS OF GARDENERS, THEIR MOTIVATIONS FOR GARDENING AND MANAGEMENT \\ PRACTICES OF BLACKACRE COMMUNITY GARDEN AND \\ LIMERICK COMMUNITY GARDEN IN JEFFERSON COUNTY, KENTUCKY
}

By

Robin Oxnard Grossman

B.A., University of Kentucky, 1997

\author{
A Thesis \\ Submitted to the Faculty of the \\ Graduate School of the University of Louisville \\ in Partial Fulfillment of the Requirements \\ for the Degree of
}

Master of Science

Interdisciplinary Studies

Environmental Education, Policy \& Management

University of Louisville

Louisville, Kentucky

December 2000 
A COMPARISION OF THE CHARACTERISTICS OF GARDENERS, THEIR MOTIVATIONS FOR GARDENING AND MANAGEMENT PRACTICES OF BLACKACRE COMMUNITY GARDEN AND LIMERICK COMMUNITY GARDEN IN JEFFERSON COUNTY, KENTUCKY

By

Robin Oxnard Grossman

B.A., University of Kentucky, 1997

A Thesis Approved on

NOVEMBER 13, 2000

By the Following Reading Committee:

Allan E. Dittmer

Thesis Director

David M. Wicks

Thomas S. Lyons 


\section{ACKNOWLEDGEMENTS}

This document is a testimony to perseverance and commitment. I would like to thank those people who encouraged me during the past two and a half years as I have worked on my master's degree and thesis. Dr. Allan Dittmer's cheerful disposition, supportive nature, and commitment to teaching and learning have helped make my learning experience at the University of Louisville rewarding. Dr. David Wicks is a whirlwind of energy and his enthusiastic commitment to the community through his work in environmental education is an inspiration. Dr. Thomas Lyons broadened my understanding of planning and environmental management and his thoroughness in reviewing my thesis is much appreciated.

I would like to thank the people committed to community gardening in Jefferson County, Kentucky for their help with this research. Thank you to Jackie Erhart, Jerie Britton, Bob Hughes, Geneva Hawkins, and all the community gardeners who participated in the study, without whose support this research would not have been possible.

Finally, I would like to thank my family for their support. The past year and a half has been a time of exponential growth as I have become a wife and a mother and have earned my master's degree. My husband, Eric, has been a pillar and an inspiration. His commitment to completing his doctoral degree, his strong work ethic, and his commitment to our family are an inspiration. Finally, thank you to my seven month old son, Gavin, who has helped me keep this research in perspective. Watching him unfold has been and will continue to be one of the greatest joys of my life. 


\section{ABSTRACT}

Using four surveys, two created by this researcher, another created by Walizcek, Mattson, and Zajicek, and a fourth created by Herbach, the researcher compared the characteristics of community gardeners, their motivations for gardening, and the management practices of the inner-city Limerick Community Garden and the suburban Blackacre Community Garden in Jefferson County, Kentucky. 33 Blackacre gardeners, 16 Limerick gardeners, two garden managers, and two garden administrators participated in the study.

The researcher hypothesized that the location of the garden could be influential in determining who the gardeners are and what their motivations for gardening are. The inner-city garden was expected to have a more diverse gardener population than the suburban garden based on census tract data for the two garden locations. In addition, the researcher expected to find marked differences in management of the two gardens based on their location and the fact that one was administered through the city government and the other through the county government.

Results indicated that the gardeners who participated in the study are more similar than different. The majority of the gardeners surveyed are white, over age 61 , have more than 15 years of gardening experience, and work between one and three days a week in the garden for one to five hours. Additionally, the majority of the gardeners surveyed grow vegetables only and use their food for familial purposes of canning or freezing, giving to family and friends, and feeding their family.

Results indicated that the community gardens provide a number of quality-of-life benefits to the gardeners. Physiological aspects of gardening, such as working in the soil, working outside, enjoying the garden colors and smells, and needing the physical exercise, were rated slightly more important for Limerick gardeners than Blackacre gardeners. Social aspects of gardening were rated slightly more important for Blackacre gardeners than Limerick gardeners. Safety in the garden was a more important issue for 
the inner-city Limerick gardeners than the Blackacre gardeners. Self-esteem aspects of gardening, such as being able to produce one's own food, being proud of one's garden, and being able to create something of beauty, were rated more important for the Limerick gardeners than Blackacre gardeners for both the mean and mode. Gardening for food security was not important for the majority of gardeners surveyed. Gaining a feeling of peace from the garden was important for both Blackacre and Limerick gardeners. Teaching one's children and family to garden received significantly lower ratings than the physiological, safety, social, and esteem categories. It was considered only somewhat important by both Blackacre and Limerick gardeners.

Results indicated that the city community gardening program is more of a grass-roots effort, with responsibilities for starting and maintaining gardens coming from the city residents, compared with the county community gardening program, which is more of top-down approach, with responsibilities for starting and managing gardens coming from the county. The two community gardening programs provide similar resources (for example, water, mulch, tilling) to the gardeners, have similar rules and regulations which gardeners must agree to, and fulfill a number of planning-like functions. Results indicated that the land use policies of the two community gardening programs do not provide community garden security. 


\section{TABLE OF CONTENTS}

INTRODUCTION $\ldots \ldots \ldots \ldots \ldots \ldots \ldots \ldots \ldots \ldots \ldots \ldots \ldots \ldots$

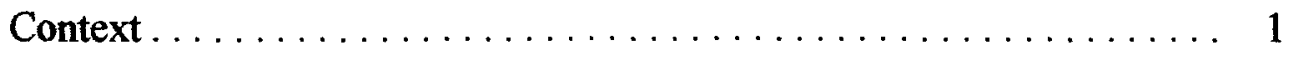

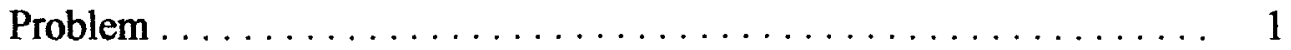

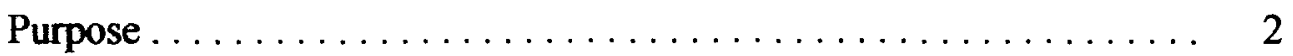

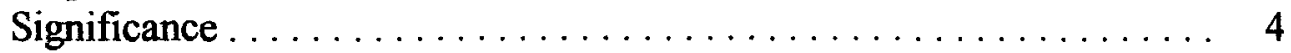

REVIEW OF LITERATURE $\ldots \ldots \ldots \ldots \ldots \ldots \ldots \ldots \ldots \ldots \ldots \ldots \ldots \ldots \ldots$

History of community gardening in America $\ldots \ldots \ldots \ldots \ldots \ldots$

Building community through community gardens $\ldots \ldots \ldots \ldots \ldots \ldots 13$

Attitudes toward and benefits of community gardens $\ldots \ldots \ldots \ldots \ldots 16$

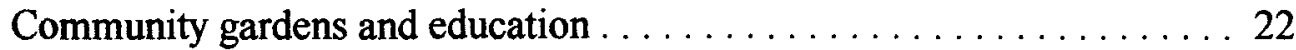

Community food security through community gardens $\ldots \ldots \ldots \ldots 24$

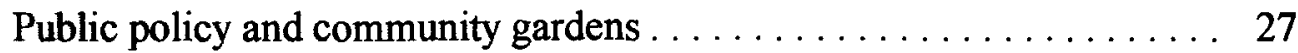

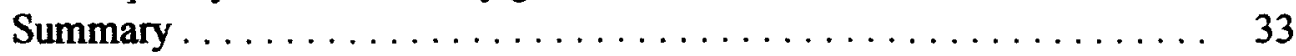

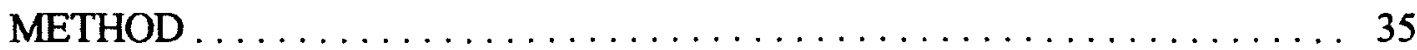

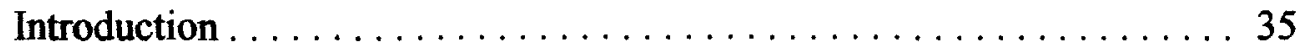

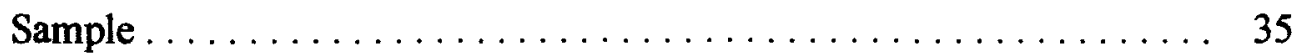

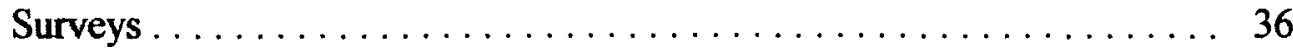

Community Gardener Survey - Part I . . . . . . . . . . 36

Community Gardener Survey - Part II . . . . . . . . . . . . . 37

Community Garden Manager and County/City Administrator Survey -

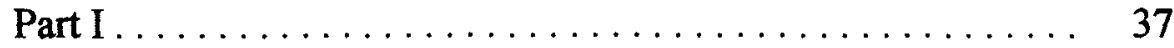

Community Garden Manager and County/City Administrator Survey -

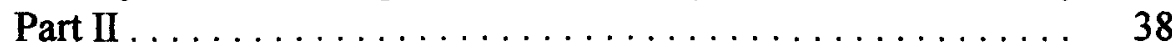

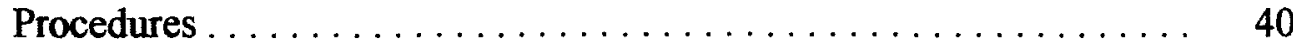

Data Analysis . . . . . . . . . . . . . . 42

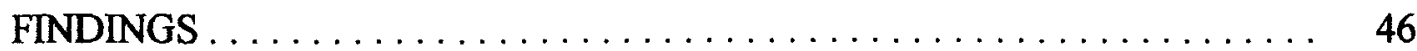

Introduction $\ldots \ldots \ldots \ldots \ldots \ldots \ldots \ldots \ldots \ldots \ldots \ldots \ldots \ldots \ldots$

Overview of the Blackacre and Limerick Community Gardens . . . . . . 46

Planning-type work of the Blackacre and Limerick gardening

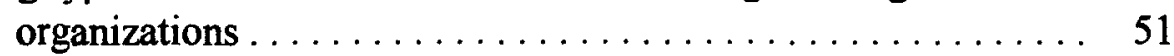

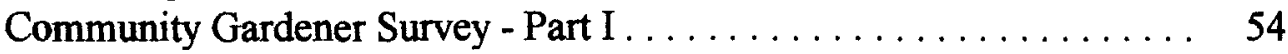

Community Gardener Survey - Part $I I \ldots \ldots \ldots \ldots \ldots \ldots \ldots \ldots 68$ 
Conclusions . . . . . . . . . . . . . . . . . . . . . . 74

Management of the Blackacre and Limerick Community Gardens . . . 74

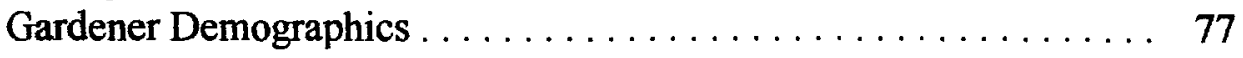

Motivations for Gardening $\ldots \ldots \ldots \ldots \ldots \ldots \ldots \ldots \ldots \ldots \ldots \ldots$

Summary .......................... 86

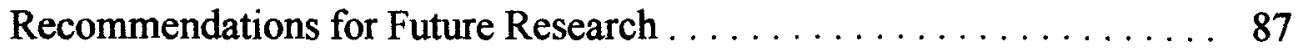

REFERENCES . . . . . . . . . . . . . . . . . . . . . . . . 89

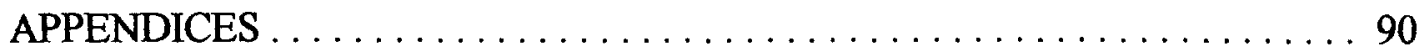

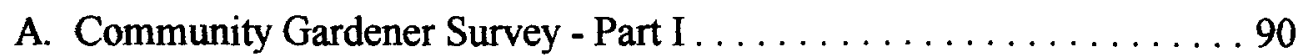

B. Community Gardener Survey - Part II . . . . . . . . . . . 92

C. Community Garden Manager and County/City Administrator

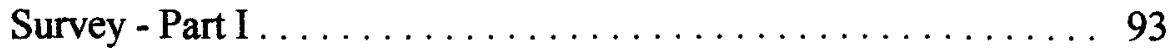

D. Community Garden Manager and County/City Administrator

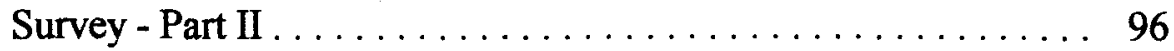

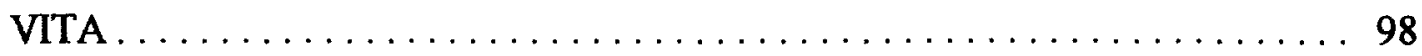




\section{LIST OF TABLES}

TABLE

1. Planning categories addressed by city and county gardening programs .. 54

2. Age of community gardeners surveyed $\ldots \ldots \ldots \ldots \ldots \ldots \ldots \ldots 56$

3. Years of gardening experience in relation to age and gender of gardeners at the Blackacre and Limerick Community Gardens . . . . . . . . 58

4. Years of gardening at the Blackacre and Limerick Community Gardens . . 59

5. Distance gardeners live from the Blackacre and Limerick Community Gardens ................................6 60

6. Hours and days per week gardeners spend at the Blackacre and Limerick Community Gardens $\ldots \ldots \ldots \ldots \ldots \ldots \ldots \ldots \ldots \ldots \ldots \ldots \ldots \ldots \ldots \ldots$

7. Kinds of plants grown by gardeners at the Blackacre and Limerick Community Gardens .62

8. Ways gardeners use food grown at the Blackacre and Limerick Community

Gardens 63

9. Reasons for gardening given by the Blackacre and Limerick Community

Gardeners 64

10. Reasons for gardening at the Blackacre and Limerick Community Gardens

11. What gardeners learn from gardening $\ldots \ldots \ldots \ldots \ldots \ldots \ldots$

12. Means and modes for quality of life statements for all gardeners surveyed at the Blackacre and Limerick Community Gardens 
13: Comparison of responses to the open-ended question, "Why do you garden?" with responses to quality-of-life statement (\#3) for physical exercise . . . 80

14. Comparison of responses to the open-ended question, "Why do you garden?" with responses to quality-of-life statements $(\# 1,2)$ for physiological aspects of gardening

15. Comparison of responses to open-ended question, "Why do you garden?" with responses to quality-of-life statement $(\# 9,10,12)$ for social connections

16. Comparison of responses to open-ended question, "Why do you garden?" with responses to quality-of-life statement ( $\# 25$ ) for food security . . . . 84

17. Comparison of responses to open-ended question, "What do you learn from gardening?" with responses to quality-of-life statements $(\# 16,18,20)$ for self-

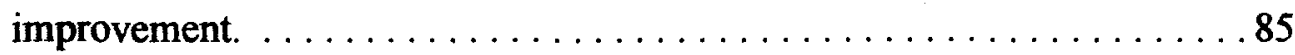

18. Comparison of responses to open-ended question, "What do you learn from gardening?" with responses to quality-of-life statement (\#14) for caring for community 


\section{INTRODUCTION}

\section{Context}

Gardening is a major American pastime. A 1994 survey by the National Gardening Association found that 30 million households in America were involved in gardening. Of the 30 million households, about one percent, or 300,000 households, were involved in community gardens (Malakoff, 1995). A community garden is an example of community open space, which is defined by Mark Francis et al. as "any green place designed, developed, or managed by local residents for the use and enjoyment of those in the community" (1984: 1). Community open spaces, including community gardens, are "usually low cost, small scale, locally controlled, and user-oriented, in contrast to traditional open spaces, which tend to be high cost, large scale, publicly controlled, and maintained by professionals or corporations" (Francis et al., 1983: 11).

A community garden is shaped by its purpose and context. The purposes for today's community gardens in America are many and varied and are quite different from community gardening purposes of the past. Today's community gardens may be aimed at teaching horticulture to children and diverting them from the streets, growing and preserving food from seed to shelf, using heirloom plants and butterfly and bird gardens to restore a sense of nature to the industrial city, and cleaning up overgrown neighborhood eyesores and pushing out drug dealers (Hynes, 1996). The primary purposes of earlier community gardens in twentieth century America have been for philanthropy, war relief, and "reform charity - of the 'haves' uplifting the 'have nots' (Hynes, 1996: x).

\section{Problem}

Community food security (CFS) is a concept rooted in community and is a "small-scale, locally owned economic development approach to feeding people" (Sustainable Food Center, 1996, i). CFS addresses a broad range of problems which affect the environment, the food system, economic opportunity and community development, including the following:

- the diminishing food safety net

- disappearing farmland and inner-city supermarkets 
- increasing poverty and hunger

- failing family farms

- rural community disintegration

- inadequate green space

- diet-related health problems

These problems are addressed through long-range planning, a community-based needs assessment, and committed participation by the community. Community coalition-building between public, private and non-profit sectors, project planning and implementation, and food policy advocacy are the basic components of the community food security methodology. (Winne, Joseph, and Fisher, 1996)

The issues which community food security is designed to address (as outlined above) could be alleviated through community gardens. A study by the Austin, Texas Sustainable Food Center entitled "Access Denied: An Analysis of Problems Facing East Austin Residents in Their Attempts to Obtain Affordable, Nutritious Food" suggested that local food production through community gardens could be an important step towards creating food security.

The purposes and contexts of community gardens vary greatly. It is unknown what role/s, if any, community gardens in Jefferson County, Kentucky play in terms of creating a food secure environment. A study such as this one could begin to broach the subject of gardeners' motivations (such as creating a food secure environment) for gardening in a community garden setting and the influence garden location may have on gardeners' motivation. Specifically, the researcher's problem is to explore the gardening motivations of inner-city and suburban community gardeners as well as to compare management practices for an inner-city and suburban community gardening program.

\section{Purpose}

The purpose of this research is to compare the characteristics and motivations of community gardeners at the Blackacre and Limerick Community Gardens in Jefferson County, Kentucky, as well as to compare management practices, looking for commonalities and 
differences in the county- and city-managed gardens. This study used surveys to explore who the gardeners at the two sites are and what their motivations for gardening are. The researcher also used surveys to look for similarities and differences in garden demographics and management practices.

The researcher chose the two garden sites to represent an inner-city and a suburban garden in Jefferson County for personal and logistical reasons. The researcher formerly worked at Blackacre State Nature Preserve next to which the Blackacre Community Garden is located. The Blackacre Community Garden is only three years old, has approximately 200 gardeners and is located on open land allowing gardeners (and anyone else who chooses) to visit it at any time. Blackacre Nature Preserve, the Woods at Fox Creek, a new subdivision, and Tucker Station Road border the Blackacre Community Garden. The Limerick Garden, on the other hand, is located near downtown Louisville in raised beds on an old parking lot and has approximately 26 gardeners. A chain-link fence surrounds the Limerick Garden and remains locked, even when gardeners are working there. A well-traveled city street, an alley, and a small park with a playground border the Limerick Garden.

The researcher hypothesized that the contrasting contexts of the two gardens may influence the gardeners' motivations for gardening and the management practices at the two gardens.

Census tract information further supports the selection of the two gardens to represent an urban and a suburban community garden. The information shows the inner-city site has higher population density, fewer homeowners, and a lower average income per individual compared with the suburban site. The following census tract information is from the 1990 census, the most recent census information available. The Blackacre Community Garden is located in a census tract with a population of zero to one persons pre acre, while the Limerick Garden is located in a census tract with a population that ranges from zero to fity persons per acre, depending on the section of the census tract. Parking lots, residential and group homes, commercial businesses, city streets, and apartment complexes make up the tract in which the Limerick Garden is located, 
while farmland, a nature preserve, and residential homes make up the tract in which the Blackacre Garden is located.

Population diversity and income vary greatly between the two census tracts. The inner-city tract, site of the Limerick Garden, is $58 \%$ white, $40 \%$ black, and a small percentage of Hispanic and other races.- The suburban tract, site of the Blackacre Garden, is $98 \%$ white and $2 \%$ black and other races. The average income was $\$ 19,701$ for the inner-city census tract as of 1990 and $\$ 52,266$ for the suburban tract. Of the occupied housing units, renters accounted for $87 \%$ in the inner-city tract, compared with $11 \%$ in the suburban tract. Homeowners accounted for $13.3 \%$ in the inner-city tract and $\mathbf{8 8 . 8 \%}$ in the suburban tract. These statistics have undoubtedly changed in ten years time; however, the 2000 census tract information would more than likely further bolster these statistics.

\section{Significance}

At first glance, the two gardens are strikingly different in terms of context, the number of gardeners, physical layout of the garden, location, population density around the garden and income of nearby population. This study seeks to determine whether significant differences or commonalities exist in gardeners' motivations for gardening and garden management practices as a function of the garden location. In addition, little research has been done on the community gardening programs in Jefferson County, Kentucky. This study is significant for the following reasons:

- Garden administrators may find documented research useful in order to support and improve their community gardening programs and educate the public about their programs.

- Garden administrators may appreciate having documented research about the community gardens for archival purposes.

- Community garden managers of the two sites can better understand the motivations of the gardeners and help meet their needs.

- Garden managers at other community garden sites may also find the research useful as they work to meet the needs of their gardeners. 
- The study contributes to the understanding of why people choose to garden in a community garden setting.

- This study distinguishes between two different community garden models, inner-city versus suburban. Commonalities and differences in garden demographics and gardeners' motivations are compared.

It is beyond the scope of this research to study all of the county and city community gardens. The researcher believes the proposed study of the two gardens will provide useful data for both the county and city garden programs. 


\section{REVIEW OF LITERATURE}

\section{History of community gardening in America}

In the late 1890 's, American municipalities, faced with economic recession, began a movement of allotment gardening, in which cities leased vacant land from private landowners for gardening uses by the urban unemployed. These late nineteenth century gardens produced a large return for the public investment and alleviated strains on food welfare purchases. Over the next one hundred years, there would be seven distinct yet overlapping periods of allotment or community gardening. Bassett (1981) has named the periods as follows: Potato Patches (1894-1917), School Gardens (1900-1920), Garden City Plots (1905-1910), Liberty Gardens (1917-1920), Relief Gardens (1930-1939), Victory Gardens (1941-1945), and Community Gardens (1970 to the present).

Potato Patches (1894-1917). The first movement of allotment gardening has been named Potato Patches by Bassett for good reason. Detroit mayor Hazen Pingree led this gardening initiative when he allocated municipally owned and privately donated vacant urban land for gardening use by the poor and unemployed during an economic recession. By 1895,455 acres of land in Detroit were under cultivation, with the principal crops being potatoes, beans and turnips. Pingree's Potato Patches, as they came to be known, garnered much attention, especially in light of their return on investment. The Poor Commission's appropriation of $\$ 5,000$ for the allotment gardens saw a return of $\$ 28,000$ worth of produce. Soon other cities began to follow Pingree's lead, not only because of the financial benefits, but also for the perceived moral and social benefits. Cultivation of vacant lots in cities was perceived as "infusing hope and self-respect in hard-working gardeners at the same time as lowering taxes for property owners" (Bassett, 1981: 2). The first American allotment gardening movement would not last, however. As prosperity increased and more workers became employed, land owners tended to reclaim the vacant lots on which gardens were located in order to put them to more profitable uses. (Bassett, 1981)

School Gardens (1900-1920). School gardens of the early twentieth century were upheld as fostering the virtues of good citizenship, economy and an appreciation of the natural 
environment. As America was making a transition from a rural to more industrial society, the school garden was seen as a place where children could be trained in the "basics of civic responsibility and the industrial work process" (Bassett, 1981: 3). A very orderly garden design and individual garden plots, rather than communal plots, were the norm in school gardens in an effort to impress upon children the value of efficiency and their individual responsibilities for later work life.

Mrs. Fannie Parsons, founder of the children's school garden in New York City's DeWitt Clinton Park, echoed this tendency toward training children to become productive, responsible citizens, when she said,

The garden was used as a means to show how willing and anxious children are to work, and to teach them in their work some necessary civic virtues; private care of public property, economy, honesty, application, concentration, self-government, civic pride, justice, the dignity of labor, and the love of nature by opening to their minds the little we know of her mysteries, more wonderful than any fairy tale. (Quoted in Bassett, 1981: 3)

Henry Parsons stressed the civic, moral and social tenets of the School Gardens in his book, Children's Gardens for Pleasure, Health and Education, when he wrote, "Here they learn what relation the products of their labor have to the welfare and progress of their country, and they will take pride in their ability to share in this welfare and progress" (Quoted in Bassett, 1981:3).

Garden City Plots (1905-1910). While the Potato Patches gardening movement was initiated as a form of welfare relief, the Garden City Plots movement was initiated as a form of neighborhood beautification. Cleanup and greening campaigns in cities claimed that neighborhood beautification and improvements, such as planting trees, shrubs, and flowers along city sidewalks, would serve to "bring happiness and prosperity to all" (Bassett, 1981: 4).

Vacant city lots were viewed as "civic blemishes" and many were claimed by school teachers and students to establish flourishing and well ordered gardens (See School Gardens). Well pleased with the improvements being made, community leaders "saw such conversions as 
the fruits of a growing civic-mindedness that abounded with educational, economic, and social nutriment for everyone" (Bassett, 1981: 4). Supporters of the gardening movement claimed its benefits reached beyond those of the earlier Potato Patches movement aimed at welfare relief and promoting self-respect and independence for the jobless. Under the Garden City Plots movement, a more diverse section of society was involved and such benefits as improving health, saving money, and providing a source of rest from the tensions of urban life were claimed (Bassett, 1981).

Liberty Gardens (1917-1920). A fourth gardening movement of the early 1900's, liberty gardens were initiated as a response to the political, social and economic context as America entered World War I. A National War Garden Commission, created in 1917 to encourage Americans to increase food production and conservation, aimed "to arouse the patriots of America to the importance of putting all idle land to work, to teach them how to do it, and to educate them to conserve by canning and drying all food that they could not use while fresh" (Quoted in Bassett, 1981: 4). Americans were encouraged to grow their own food and free up the national agricultural supplies for the soldiers and allies oversees. Campaigns called for Americans to become "soldiers of the soil," "to plant for freedom," and "to hoe for liberty." These campaigns called on Americans to show their patriotism and support for democracy through their own efforts on the homefront; by taking up a hoe, instead of a rifle. While gardens of the past had been associated with poor-relief, civic-mindedness and beautification, a new set of values were now associated with gardening under the leadership of the National War Garden Commission, including the following:

(1) The vacant-lot garden was a sign of patriotism in its transformation of the most conspicuous of all "slacker lands."

(2) The vacant-lot garden was the epitome of conservation in its organization and operation.

(3) The vacant-lot garden symbolized the unity, order, and strength of the forces at home. 
(4) The vacant-lot garden signaled a decrease in food transport, making room for munitions and other war materials on the nation's railways. (Bassett, 1981)

Proponents touted the benefits of the liberty gardens as encompassing an even greater cross-section of society than the previous gardening movements and of making vacant-lot cultivation a dignified and responsible thing to do. The National War Garden Commission reported that 3,500,000 war gardens produced $\$ 350,000,000$ worth of produce in the year 1917 . Production increased in 1918 to $5,285,000$ gardens producing $\$ 525,000,000$ worth of produce. (Bassett, 1981)

Relief Gardens (1930-1939). The Great Depression saw the establishment of gardens which were reminiscent of the Potato Patches gardening movement of the late 1800 's and early 1900's (Bassett, 1981). Relief gardens were initiated as a means of supplementing Americans' nutritional needs and providing work for the unemployed. Just as the other gardening movements proved to be temporary measures to address larger social problems during a crisis, the Relief Gardens movement also proved to be temporary. The federal government discontinued its support for the relief gardening program in the late 1930's as the United States Department of Agriculture established the food stamp program for farm surplus products (Hynes, 1996).

Two types of relief gardens, the individual plot or allotment plan and the undivided, large-tract design or industrial plan, were popular during this period and reflected two very different ideologies. Individual plot gardening gained support for the virtues of self-help, individual control of one's crops, and "a spirit of independence that kept many from seeking direct (welfare) relief' (Bassett, 1981: 6) (parentheses mine). In Cairo, Illinois, for example, many poor and unemployed people found their sole source of subsistence through cultivation of individual garden plots, some as large as a half acre. Supporters of the individual garden plan claimed that it benefited those who had lost virtually evesthing, from their jobs to their savings, and even their homes. Tilling the land for subsistence provided a means for maintaining that spirit of independence. 
Proponents of the industrial garden plan pointed to the collective benefits of this type of relief garden. Rather than individuals tilling their own plots, under the industrial garden plan, large tracts of land were cultivated, managed by a foreman, and worked by citizens who had a specific job to do. Benefits claimed by proponents of the industrial plan included (1) the community as a whole would benefit as opposed to the individual, (2) the greatest amount of food for the greatest number of people would be provided, and (3) nongardeners who lived in industrial cities would be better able to contribute to the industrial garden because their gardening work would more closely resemble the factory work they knew (Bassett, 1981).

Victory Gardens (1941-1945). The National Victory Garden Program was initiated as an effort to ease the demand on American commercial vegetable supplies for use by soldiers and allies overseas during World War II. In addition, the program was aimed at "maintaining the vitality and morale of Americans on the homefront through the production of nutritious vegetables in the outdoors" (Bassett, 1981: 7). As with the Liberty Gardens movement, national campaigns called on Americans to take up the hoe as a sign of their commitment to the American ideals of life, liberty, and the pursuit of happiness. Campaign slogans included, "Food is no less a weapon than tanks, guns, and planes," and "the duty of every loyal citizen is to do everything possible, to accept any sacrifice, so that there shall be plentiful supplies of food for the fighting forces and facilities for delivering them" (Quoted in Bassett, 1981: 7).

By $1944,20,000,000$ victory gardens produced 40 percent of the fresh vegetables consumed in America. As with the other gardening movements, proponents touted the many benefits of gardening, including self-respect, independence, civic involvement, patriotism, and valuable recreation (Bassett, 1981). Gardening during the Victory Gardens movement was becoming popular among an ever increasing and diversified (in terms of gender, profession, class level) audience. As a sign of the increasing popularity of gardening, between 1917 and 1942 circulation of garden magazines increased from 300,000 to 5,500,000. (Bassett, 1981) Just as the other gardening movements came to a close because of the end of a crisis period and/or the desire for more profitable land uses by land owners and developers, the Victory Gardens 
movement began to dwindle as the need for food production diminished at the end of World War II (Punch, 1992).

Towards the late 1940's, society's interest in gardening began to shift again as pesticides, first produced during World War II for the control of lice and mosquitoes, were introduced to the -American homefront for agricultural and horticultural uses. The manicured suburban lawn was promoted and could be maintained by use of pesticides. Many community gardens would be abandoned for the more controlled setting of manicured lawns, golf courses, and landscaped plantings which came to be prominent around corporate centers. (Hynes, 1996)

Community gardens (1970 to the present). The current gardening movement of community gardens echoes some of the tenets of the earlier garden movements, while also showing signs of innovation. Just as the earlier gardening movements were seen as ways to spark Americans' self-reliance, civic responsibility, and patriotism, today's community gardens reflect these same ideals. While the first American gardening movement, Potato Patches, was geared towards the poor and unemployed, today's community gardens are initiated by or geared towards the needs of diverse groups, including the young, old, homeless, inmates, pregnant teenagers, the handicapped, wealthy, and poor. According to Bassett (1981), today's community gardens more closely resemble the "ideals of private ownership, self-reliance, and the pursuit of individual happiness," through the cultivation of individual garden plots, such as those which were cultivated during the Relief Gardens and Victory Gardens movements.

A community garden may provide food for homeless shelters. In Cathrine Sneed's San Francisco Horticulture Project, jail inmates grow vegetables on an eight-acre farm, helping to feed thousands of homeless people who visit soup kitchens. Many graduates of the Horticulture Project have gone on to work with Sneed's Garden Project, a community service and job skills training program rooted in gardening (Hynes, 1996).

A community garden may be initiated as a way toreclaim blighted inner-city land. Sister Maureen O'Hara of the Penn State Extension Urban Gardening Program helped created a community garden on a vacant lot that had degenerated into a local landfill. Sister O'Hara and 
others found car batteries, syringes, tires, garbage, broken concrete and glass on the vacant lot. Not to be deterred by the urban eyesore, Sister O'hara created a demonstration garden, even salvaging some of the waste for use in the garden. Foundation stones were used to frame gardens and walkways and broken chunks of concrete were mixed with a cementitious material and used for boulder-like supports for raised herb beds (Hynes, 1996).

A community garden may be a way to preserve culture. In Norris Square, a largely Hispanic neighborhood of Philadelphia, people have come together to grow plants native to their homelands and create murals of their cultural roots. (Hynes, 1996)

A community garden may serve as an outlet for homeless children. Philadelphia's Project Rainbow is a residential program for homeless women and their children. The children who live at Project Rainbow grow a courtyard garden. (Hynes, 1996)

A community garden may contain individual plots, which are designed and maintained by individuals, or communal plots in which people tend the garden and share the harvest together. A small fenced-in concrete space outside an inner-city apartment complex may be the site for a community garden with raised beds in which to grow plantings. A larger piece of land on the edge of town may also be the site for a community garden.

A community garden may serve as food security for a family and community. Community food security (CFS) is defined by Winne, Joseph and Fisher (1996) as "all persons in a community having access to culturally acceptable, nutritionally adequate food through local non-emergency sources at all times" (1). In 1992, for example, low-income families in Philadelphia realized a return (in food produced) of seven dollars for every one dollar invested in their garden (Hynes, 1996). These families grew an average of $\$ 700$ worth of produce per household plot. An urban gardener polled by Patel (in Hynes, 1996) stated, "I garden mainly to save money and provide vegetables to meet our family's needs year-round" (91).

A number of community gardening organizations founded in the 1970's are still active and strong today in the year 2000. In 1974, Ernesta Drinker Ballard, a prominent horticulturist, helped establish Philadelphia Green as an effort to emphasize self-help and reciprocity between 
greening organizations and the gardener. By 1994, Philadelphia Green had helped establish more than 2,000 community gardens in low and middle-income neighborhoods of Philadelphia (Hynes, 1996). In 1978, the American Community Gardening Association (ACGA) was formed by community gardeners and organizers "to promote community gardening in urban, suburban, and rural America as a tool for political organizing and community development" (Hynes, 1996: xiv). The ACGA remains strong today and is a source of technical assistance and support for community gardens nationwide. New York City's Green Guerrillas was formed in the mid-1970's by a group of landscape professionals to assist people who wanted to start gardens on vacant lots. By 1985 over 1000 gardens had been established in New York City (Hynes, 1996).

Just as with previous garden movements, many of today's community gardens remain vulnerable to development pressures. Use of vacant city lots for community gardens can be both a success and a struggle as many community gardeners are faced with the land on which their garden is located being sold for more profitable uses. Bassett's 1981 urging that "if community gardeners today wish to profit from their tradition, they would be wise to have the title to their garden site" still holds true today.

\section{Building community through community gardens}

This section highlights how coming together to create, plan, and implement a community garden served to strengthen one Chicago inner city community.

Severson (1990) writes of the restorative benefits a community garden has had on a neighborhood in Chicago as neighborhood residents combined the "power of organization with the power of nature." The 1900 block of West Potomac was considered to be decaying and unsightly with 14 vacant lots, over an acre of weeds and trash, and 12 of the 14 vacant lots located on the same side of the street. Residents commented, "It was horrible. I didn't want to move here," and "These lots were just really dirty. . I romember thinking to myself, boy, there's got to be bodies buried out there. It was awful. The weeds had grown up. It looked like frozen marshgrass" (Severson in Francis and Hester, 1990). The idea for a community garden came 
about during a meeting of a neighborhood group concerned with crime and housing. A local community organizer gave the group the idea for a community garden, and the group then met with the Chicago Botanic Garden's community garden organizer who showed them how other Chicago residents had started gardens.

The neighborhood group chose three lots on which to start their garden, one city-owned and two privately owned. The lots were the largest contiguous area of vacant land, received full sun, and appeared to have decent soil as evidenced by the growth of weeds and grass. In the spring of 1987, the group, with help from interested neighbors, began clearing rubble and trash, including two boats and four cars, which were removed by city crews. The site plan for the garden lots was created by a member of the neighborhood group, a student in architectural history. The plan included areas for children to play, a brick patio, a wildflower meadow, fruit trees, benches, shade trees, and 20 vegetable plots, measuring 4' $x 16^{\prime}$ each. (Severson in Francis and Hester, 1990)

As the plans for the garden progressed, more and more people got involved. In addition to the commitment by neighborhood residents in creating the garden, the neighborhood group received funding from the Chicago Botanic Garden and Kraft, Incorporated. During the first season, eight vegetable plots were ready for planting. Six of the gardeners found their first gardening experiences to be very rewarding experience. As one of the first-time gardeners stated,

There's something nice about planting something, keeping something alive. I really feel like I'm making a contribution to society. That's a big problem in contemporary life. Everybody just takes and takes and takes. You buy things. You're constantly in a consuming sort of situation. With the garden, I really never feel like I'm consuming anything. I feel like I'm changing things. I feel like I'm adding something. (Severson in Francis and Hester, 1990) 
In addition to feeling they were contributing to society and building up their community, gardeners also expressed the restorative effects on nature as a result of the community garden. As one gardener put it,

I was interested in planting anything that grew. I just wanted to see a little improvement and if in any way planting a garden would help, I'd do it. . It kind of brings you closer to God. To me, that makes me feel good. It's like, wow, you hear about all this pollution and all this underground poisoning, but yet this little plot of earth can still produce.

(Severson in Francis and Hester, 1990)

In recognition of the community building aspects that the creation, planning, and implementation of a community garden can have, the community gardeners of the 1900 block of West Potomac named their project, "United We Sprout." The garden continued to grow that first season, with 12 new gardeners signing up. A fall harvest festival was held in recognition of the gardeners' first successful gardening season. As the gardeners realized what they had accomplished, many became inspired to preserve their gardens from future development. As one gardener said, "We would like to just stake out this large section and say, 'No buildings. No development of any kind. This is always going to be a park" (Severson in Francis and Hester, 1990). Hopefully that determination would inspire the "United We Sprout" gardening organization to effect policy. As of 1987, Chicago had no open space objectives.

In the year 2000, are the gardens in the 1900 block of West Potomac still strong? The researcher was unable to find information about the current status of the gardens. Perhaps they succumbed to development pressures and the city reclaimed the lot it owned or the other land owner sold his or her lots. Perhaps the gardeners lost interest in the gardens. Perhaps, the "United We Sprout" organization has remained strong in its 14 years since inception, has organized to influence urban land policy in Chicago, and is still building community in the 1900 block of West Potomac. 


\section{Attitudes toward and benefits of community gardens}

Much anecdotal research has shown that community gardens are beneficial to people and communities; however, until the past twenty years, little quantitative research had been conducted in an effort to explore the impacts of community gardens. Malakoff argues that anecdotal evidence may not be enough to convince politicians, developers, and taxpayers to spend time and money on community gardens. Quantitative evidence may be necessary to convince those persons, whose support is often necessary for the preservation of community gardens, that "greening is a good investment" (Malakoff, 1995).

Hynes, on the other hand, argues that while she encourages her students to use both quantitative and qualitative data, she sees the inherent dilemmas in quantifying the impacts of community gardens. Tangibles, such as crime statistics and market goods (for example, amount and kind of food produced), are generally easier to quantify than intangibles, such as community-building, leadership, self-esteem, and peace of mind (Hynes, 1996). Hynes underscores the problematic nature of placing a value on community gardens versus more profitable uses when she writes, "Do we lose the twenty gardens of the four-acre Cornell Oasis to sixty townhouses because the value of its biodiversity is not possible to calculate in dollars, and the benefit of tranquility to the gardeners is estimated to be $1 / 1000$ th of the return on the development project?" (Hynes, 1996: 160). In her book, A Patch of Eden, America's Inner-City Gardeners, Hynes uses qualitative methods, stories told by gardeners themselves and about gardens in Harlem, Chicago, San Francisco, and Philadelphia, to explore a number of community gardening issues, including, but not limited to: garden financing, reclamation of contaminated land, community building, what success means for a community garden, and the role of women in the community garden movement. For Hynes, the gardeners' stories "may hold more strategic and political power than the rigor of quantitative data" (Hynes, 1996: 160). Two of the community gardening projects she studied will be highlighted in this section.

As both quantitative and qualitative measures are important sources of data for better understanding community gardens and their impacts on communities, this section will highlight 
some of the quantitative and qualitative research concerning attitudes toward and benefits of gardening and community gardening.

Quantitative studies

Kaplan and Kaplan are leaders in the field of understanding nature experiences through the collection of quantitative data. In their work, The Experience of Nature, A Psychological Perspective, Kaplan and Kaplan (1989) sought to provide readers with a scientifically based, readable, and helpful book for understanding how people feel about nature experiences. Of the many themes the Kaplans study, they and their students' research on the satisfactions and benefits people derive from contact with natural environments, both distant and nearby, everyday natural environments is particularly pertinent to the discussion of the attitudes toward and benefits of community gardens.

In one study, conducted in 1976, a two-page questionnaire was sent to members of the American Horticultural Society (AHS). 4,297 members responded to the study. The questionnaire included questions which required participants to rate scales. This approach did not prove to be restricting as many of the participants included letters and comments. The Kaplans chose the readers of Organic Gardening and Farming (OGF) as a comparative group for the study because they appeared to represent different gardening practices and backgrounds. The members of the AHS tended to be more affluent than the average gardener and more likely to grow flowers than vegetables. Of the OGF comparison group, 240 readers responded to the study. The OGF participants tended to be younger, less affluent, and more likely to grow vegetables than the AHS participants.

The study was analyzed for how participants rated the importance of several gardening satisfaction categories, including (1) Peacefulness and Quiet, (2) Nature Fascination (working in the soil, tending plants, watching things grow), (3) Tangible Benefits (growing and harvesting food), (4) Sensory (walking in the garden, creating something of beauty), (5) Share-Tangible (sharing produce and flowers), (6) Novelty (trying new plants), (7) In My Control (proving to myself what I can do), (8) Share-Knowledge (sharing my gardening knowledge with others), and 
(9) Tidy and Neat (how neat and orderly things look). Participants rated the categories from one to five, with one meaning not important to five meaning extremely important. Among the study results, the data indicated that both OGF and AHS gardeners found the tangible benefits of gardening, such as producing and harvesting one's own food, were important, but they were more important for OGF gardeners. Additionally, the categories peacefulness and quiet and fascination with nature were very important for both OGF and AHS participants. Results of this study and a prior study by Kaplan and Kaplan indicate that nature fascination plays a central role as a source of gardening satisfaction. (Kaplan and Kaplan, 1989)

A related study to the Kaplans' research was conducted in 1996. The objectives of a study by Waliczek et al. (1996) were to "examine community gardeners' perceptions of their quality-of-life and what influence race, gender, and city size had on this perception."(Waliczek, 1996). Researchers based the study methods on the categorization method used by Kaplan and Kaplan (1989) in their studies. While the Kaplan and Kaplan study was aimed at gardeners from two national groups, the American Horticultural Society and readers of Organic Gardening and Farming, the study by Waliczek et al. was aimed at community gardeners from across the nation. Study participants rated the importance of 24 quality-of-life statements, which were based on Maslow's hierarchy of human needs model, which progresses from physiological, safety, and social needs to self-esteem and self-actualization needs. Participants rated the statements, such as the physiological statement "I like to work in the soil," from one, being not important, to five, being extremely important. (For the complete list of 24 statements, see Appendix B). The researchers mailed 1,108 surveys with self-addressed stamped envelopes to 46 community garden coordinators nationwide in 1992. Coordinators were asked to distribute the surveys to community gardeners who voluntarily agreed to participate. 361 gardeners responded from 36 community garden sites.

Survey results indicated that community gardens rovide many quality-of-life benefits to community gardeners. African-American and Hispanic gardeners indicated that community gardens were extremely important for many of the quality-of-life factors. Both male and female 
gardeners indicated they benefited similarly in importance from community gardens; yet, female gardeners rated higher the importance of saving money and the beauty within the garden. When results were compared for city size, ranging from small, medium, and large metropolitan cities, only four of 24 statements indicated a significant difference between perceptions of importance of the quality-of-life statements. Results indicated the mean for most statements was higher for New York gardeners than those in Los Angeles.

Researchers found the most interesting findings were those that revealed that the "garden is meeting quality-of-life needs on the higher levels of esteem and self-actualization" (Waliczek et al., 1996). These findings corresponded with findings from the Kaplans' study, cited above, which found that the main reason home owners garden is for "peace and tranquility" (Waliczek et al., 1996). Researchers found the use of Maslow's human needs model effective in showing differences among racial/ethnic groups. Results indicated that African-American and Hispanic gardeners consistently rated the gardening benefits higher than Asian and Caucasian gardeners. Researchers concluded that the findings could have "special implications for economically disadvantaged areas in larger cities where other resources are generally sparse" (Waliczek et al., 1996).

\section{Qualitative studies}

Two community gardening projects, which were highlighted in Hynes' A Patch of Eden, America's Inner-City Gardeners, will be shown as examples of qualitative studies used to understand the benefits of and attitudes toward community gardens.

The Horticulture Project was the inspiration of Cathrine Sneed, a former counselor at the San Francisco County Jail in San Bruno, who in 1982 set out to teach inmates how to grow flowers and vegetables (Hynes, 1996). The program was such a success, that in 1991, the Garden Project was established for "graduates" of the Horticulture Project. Participants of the Horticulture Project work an eight-acre area of land and sign up for various jobs, such as weeding, harvesting, composting, tree crew, and bed preparation. A horticulturist teaches gardening classes, whose discussion is not limited to how to plant a tomato or till a garden bed. 
In one class, participants were asked, "If the garden has helped you in any way, please tell us" (Hynes, 1996: 43). Students responded, "It gives me responsibility and unity," "The garden helps us to focus," "I learn respect for life," "Gardens teach me self-control," and "I get peace of mind." For these Horticulture Project participants, the lessons learned from gardening will carry over into their lives outside of jail. Once released from jail, many of the Horticulture Project participants have gone on to work with Sneed's Garden Project, an organic market garden and community service program.

Sneed's idea for the Horticulture Project was initially met with opposition by the jail overseer, Lieutenant Robert Limacher. After witnessing first hand the changes in attitudes between those inmates who are part of the project and those who are not, Limacher firmly supports the gardening program. Comparing gardening inmates with non-gardening inmates, he says of the gardeners, "They don't have the institutionalized jail mind. They develop more self-awareness and are more able to hold themselves accountable for what they did and what they don't want to repeat" (Hynes, 1996: 41).

While the Horticulture Project helps instill greater self-respect and self-control, does it really help prevent more crime once people are freed? Although Sheriff Michael Hennessey does not have time to conduct a recidivism study, he believes that Sneed's gardening projects help motivate people, build their self-esteem, and help keep them from returning to crime. Based on his own experiences with inmates and former inmates, Hennessey is certain the gardening program helps people "get themselves out of the recurrent loop of crime" (Hynes, 1996: 49).

From San Francisco's Horticulture Project and Garden Project to Chicago's community gardens, such as the Cabrini Greens, Hynes writes of the benefits of and attitudes toward gardening, and the challenges faced by the gardeners and their organizations. The Cabrini Greens are gardens whose organic produce, tomatoes, lettuce, peppers, and potatoes, are sold to nearby restaurants and a company for making potato chips. The gardeners are girls and boys, ages ten to fifteen, who are residents of the Cabrini-Green public housing project. They and others like 
them in the city's housing projects "have witnessed tragedy and terror that we associate with war in remote parts of the world, and they have felt the fear and trauma that those who live through wars do" (Hynes, 1996: 119). Yet out of that trauma, a project like Cabrini Greens can help create something positive in their lives.

Asked what they like about the garden, kids responded, "digging, planting seedlings, and watching them grow," "planting pretty things," and "earning money, earning money, earning money, in that order" (Hynes, 1996: 123). Gardeners earn about \$250 for the season based on hours worked, as of 1996. Children not only receive the nature fascination, sensory, and economic benefits of gardening at Cabrini Greens, they also learn about community organizing and practical skills, such as doing business math oriented around figuring costs associated with a market garden and learning computer programs that simulate a garden plan.

While there are many benefits of the garden to the gardeners and the restaurants which receive their produce, the Cabrini Greens project faces the economic challenge of being a self-sustaining project. Some people do not think the project can work. Money is needed for tools and equipment and some potential sponsors in the nonprofit arena have been turned off by the market-oriented approach of the project. Additionally, from the consumer point of view, there are challenges to selling produce to supermarkets which have already established their suppliers and are accustomed to receiving the produce year round. While Cabrini Greens' produce is fresh, local, and organic, it is seasonal produce, and most consumers are accustomed to eating what they want when they want it, without regard to the seasonal nature of food and what their local growing conditions are best suited for.

In light of the problems community greening projects may face, from preservation and land use issues to economic viability to positive support and encouragement, Hynes argues for the positive impact of community greening projects on individuals and communities, for as she says, "community gardens are one of our most participatory local civic institutions, and among the few living landscapes of our cities" (Hynes, 1996: 160) 


\section{Community gardens and education}

The educative nature of community gardens is immeasurable. Learning to produce one's own food can engender a feeling of self-reliance and self-respect, an independence from the global food system we have come to rely on in the late twentieth and early twenty-first centuries. Local food production can also engender educative opportunities for understanding one's local economy and contributing to a small-scale, local economic development approach to feeding oneself and one's community. Examples exist throughout the country where community gardens have served as tools for learning about one's local economy, teaching math, science, literature, and more to elementary and secondary education students and adults alike. This section will highlight some of the national efforts linking community gardens and community greening projects with education.

A group of teenage girls in foster care grew their own organic garden in Austin, Texas in 1995 and sold their produce to a local Mexican natural foods restaurant and at a local farmer's market. Junior high students in Austin used their garden as a core component of their science and math curriculums. In addition they sold their produce at their school during the spring and summer. (Growing Together, 2)

The community greening and open space program of New York City's Harlem neighborhood, the Greening of Harlem Coalition, offers ample opportunities for learning. Bernadette Cozart, a founder of the Coalition, works with children and adults to create gardens. Cozart works with school children during the winter, designing the garden, starting seeds, and offering her botanical guides as educational aids for the children. In the spring, she then helps implement the children's vision for their gardens. Cozart believes every school in Harlem should have a garden or greenhouse or horticultural resource center, which could serve as "the basis for ecological science in Harlem for adults as well as kids" (Hynes, 12). The educational opportunities of gardening abound and can reconnect kidwand adults alike with nature. As Cozart says, "kids here are so removed from nature they don't know that just about everything comes from nature - their clothes, their houses, their food" (Hynes, 13). 
In Chicago, Illinois, 26 high school students spent their summer learning about water quality and career opportunities in environmental sciences, while working to reclaim blighted inner-city lots, stenciling “Don't Dump!" signs on storm drains, and educating others about water quality. The students are part of an initiative by the University of Illinois Extension and the Illinois Environmental Protection Agency called SOUL, Save Our Urban Land. The reclaimed vacant lots have been transformed over three summers into community gathering locations with vegetable garden plots, flowers, shrubs, and shaded walkways. As part of the program, qualitative research on the community's perception of the students' work was conducted.

Thirty-one neighbors who live near one of the reclaimed lots were polled to learn their reactions to the project. Results showed that $84 \%$ of survey participants had noticed the reclaimed lot and $16 \%$ had not. When asked what one word they would use to describe the lot prior to its being cleaned up, words such as "ugly," "junky," "dangerous and unfit," and "a hazard" were given. In response to the question to describe how the lot looks after the students' work, words such as "beautiful," "fantastic," "100\% improvement," and "creative" were used. SOUL students were described as being dependable, cooperative, hardworking, and helpful. In response to being asked how SOUL has changed the community, neighbors said, "It has gotten rid of the junkies that used to hang out there," "It has made it more livable," and "The project makes the vacant lots look like someone cares about the community." Presently, SOUL is administered by the University of Illinois Extension under a three year grant of $\$ 235,000$. (http://www.urbanext.uiuc.edu/programs/soul.html)

The SOUL project is important to both the students involved and the community members who have benefited from the reclamation of the blighted lots and the establishment of community gathering places, but this researcher wonders what will happen if and when the financial resources run dry. Will SOUL become self-sufficient and continue to improve lots, educate about water quality, and most of all, maintain those gardens and gathering places it has helped establish? One issue not addressed by the website for SOUL is land ownership of the 
SOUL gardens. Who owns the gardens, the city, or are they privately owned or leased? As evidenced by the history of previous community garden projects and movements, community gardens have been subject to development pressures and have often been destroyed or abandoned after times of crisis have passed. Hopefully, SOUL and other national projects linking students, inmates, the elderly, and other groups with community development and educational opportunities through gardening and greening efforts will continue to find the resources and support necessary for their longevity.

\section{Community food security through community gardens}

Kathleen Fitzgerald of the Sustainable Food Center in Austin, Texas writes of community gardens as often being the first step in building local food security. She writes, "gardens give power . . They offer tangible examples of the abundance the community can create for itself and give confidence for more ambitious projects" (1996, Sustainable Food Center). Fitzgerald and the Sustainable Food Center created the guide "Growing Together," a resource for planning, implementing, and managing a community garden. The need for community gardens in Austin and for the resource book were established as the result of a study entitled "Access Denied: An Analysis of Problems Facing East Austin Residents in Their Attempts to Obtain Affordable, Nutritious Food."

The study found that the Eastside area of Austin did not offer food security to its residents. Only two supermarkets were located in East Austin, both being smaller and one more expensive than similar stores in other parts of town. Securing transportation to food stores was found to be difficult for residents. Many low-income residents relied on expensive convenience stores to do their food shopping. The study found that only five of the 38 convenience stores located on the Eastside offered ingredients for a balanced meal and while all the stores stocked alcohol, only 18 carried milk. Emergency food was distributed in the Eastside area by 20 agencies. Based on the study's findings, Eastside residen were not living in a food secure environment, but the resources did exist in the community to create local food security. 
Options which could be implemented in the Eastside area to create a more food secure environment included the following:

- Incorporation of food system planning into plans for neighborhood revitalization through a Food Policy Council.

- Financing and technical assistance programs targeted to food stores in low-income communities. The formation of grocer coops that could offer group purchasing and shared warehousing for small store owners.

- Local food production through community gardening programs and urban farms.

- Neighborhood food-buying clubs.

- Support for farmers' markets and produce stands.

- Innovative education about food and how to prepare it.

- Shopper shuttles, reduced fares and other transportation solutions to help people get to stores (Sustainable Food Center, 3)

The study suggested that local food production through community gardens could be an important step towards creating food security. Vacant land is plentiful in East Austin and could be utilized for community gardens. The city could provide water for community gardens at a fraction of the cost spent on emergency food programs. A $4 \times 16$ foot garden plot could provide a fresh vegetable for a family of four every day of the year. (Sustainable Food Center, 20)

While the study recognized the importance of partnerships, financial assistance, educational outreach, and transportation needs in creating a food secure environment through community gardens, it did not recognize the importance of community garden security. For example, if the community gardens are leased from the city and no long-term policies are in place to preserve the gardens, they could become subject to the whims of development pressures. Without community garden security, long-term food security through community gardens would be problematic. Kirschbaum addresses the options for creating community garden security. Those options are reviewed in the following section, Public policy and community gardens. 
Hartford, Connecticut is one community which has holistically approached the food security issue. With the foundation of the private, non-profit organization Hartford Food System (HFS) in 1978, the community began to assess what problems in food security existed at the local, state, and national level and how they could be addressed. In its twenty-plus years of operation, the Hartford Food System has implemented both long and short-term projects in collaboration with local government, schools, for-profit businesses and corporations, such as supermarkets, the Department of Agriculture, local social services, churches, and more.

The organization has analyzed food security influences and problems and responded with programs, projects, and policies. For example in the period from 1978-1982, the organization found food price inflation and decreased regional food self-sufficiency and energy dependence to be significant problems. In response, the Hartford Food System, through collaboration with local organizations, the Community Renewal Team, the City of Hartford, the Co-operative Extension Service, and the Knox Foundation, established food buying clubs, farmers' markets, community gardens, community greenhouses, youth gardens, and a community cannery. The HFS did not stop with those projects however, as research revealed other problems in the area. In the period from 1983-1987, the HFS focused on the problems of a rise in demand at Emergency Feeding Sites, a rise in unemployment, needs of the elderly, and a "Poor Pay More" study to influence how it would respond. Programs such as a local foodbank, commercial greenhouse and cooperative supermarket, elderly programs, such as delivery services and senior stores, and coupon programs, such as WIC (Women Infants, and Children) were implemented.

From 1993-1995, the Hartford Food System focused on the influences and problems of community food security, downtown depression, and an "Urban Grocery Crisis" study to develop its program response. The Holcomb Farm Community Supported Agriculture, the Main Street Market, and a school program called "Farm Fresh Start" were established. In addition, the HFS addressed policy at the state level, began organizing nationally and offering technical assistance, worked on state food security, and developed the Connecticut Food Security Coalition. (Winne, Joseph, and Fisher, 1996) 
The Hartford Food System organization demonstrates that community food security is a complex and multi-faceted issue requiring the collaboration of local, state, and national groups, the know-how to research and understand the current influences and problems, and the perseverance to develop and implement projects and policies which will address the problems.

\section{Public policy and community gardens}

Many community gardeners have learned first-hand how important community garden security can be as they have watched their gardens and years of hard work be abolished right before their eyes. A case in point is the Esperanza garden, a New York City community garden, which lost a fierce battle with development pressures and the political and legal system when it was seized and demolished in February, 2000. Mayor Rudolf Giuliani's administration wanted to clear the garden to make room for low-and middle-income housing, while community advocates saw the garden and others like it as "solace and scenery in a city dominated by asphalt and concrete" (Chivers, 2000, February 16).

The Esperanza garden had the legal support of the state's attorney general's office, which, on the day the Esperanza garden was razed, was in court trying to stop the destruction. While lawyers were making their case in support of the Esperanza garden, demonstrators, including gardeners and garden supporters, chained themselves to concrete blocks imbedded in the garden or fences in hopes of preventing their garden from being demolished. As many as 150 gardeners and garden supporters rallied to the aid of the Esperanza garden chanting "New York City has got to breathe. More gardens, more peace." After a tense standoff with police that lasted over 12 hours, the garden supporters began to lose ground. Many were cut free of their chains and carried away to local precincts to be charged with obstruction of justice, resisting arrest, and trespassing. In a matter of hours, the garden, with its many sculptures and plantings, was bulldozed and trampled. One gardener responded, "It took 22 years to create this beautiful space, and they completely destroyed it in a couple of hours" (Chivers, 2000, February 16). In the early afternoon, after the garden had already been razed, the State Supreme Court finished 
hearing the lawyer's case and ruled to block the city from moving against 174 other lots until the court had the chance to meet again the following month.

\section{Creating community garden security through public policy}

The plight of the Esperanza garden clearly demonstrates the need for community garden security. Many of New York City's gardens and others nationwide have faced the same pressures as the Esperanza garden, even while having the support of officials to garden on vacant city lots. Kirschbaum (2000) argues for the political involvement of community gardeners in an effort to preserve their community gardens. Community gardeners must become part of the public discussion among officials and policy makers regarding the benefits and effectiveness of community gardens as a tool for achieving "desirable and quantifiable goals: food security, neighborhood stabilization and revitalization, reduction of crime, job training, recreation, therapy, and community building" (Kirschbaum, 2000: 2).

Kirschbaum (2000) argues there are a number of options for community gardeners to preserve their gardens, some options more long lasting and appropriate than others. Land trusts, leases, conservation easements, and land ownership are several options for preserving gardens, while other options are aimed at the state and local policy level. Local policy measures for preserving land for community gardens include having community garden goals as part of a community's comprehensive plan. In addition, creating local ordinances "that set up a system to inventory and lease vacant land or zoning ordinances that designate land as open space" could provide some protection, however "open space use" is often defined in many ways and use of the land for community gardens is often seen as an interim measure (Kirschbaum, 2000). In many instances, community gardens operate on city-owned vacant lots and are leased for a short term period, one or two years, with the chance of renewing the lease indefinitely. This policy however, tends to promote "instability instead of enduring goals" (Kirschbaum, 2000: 4). Land ownership is another option for community gardeners to control of their gardens, however, clearing title to vacant urban lands can make securing ownership extremely difficult. Oftentimes, lots are burdened with unpaid property taxes and other liens, and transfer of title can 
be extremely difficult. A nonprofit land trust can be a successful, long-term approach to preserving open space for community gardens. In Boston and Philadelphia, for example, nonprofit land trusts, in which land is "permanently owned and held in trust for public use," have been measures for preserving successful community gardens (Kirschbaum, 2000). Half of Boston's gardens are protected through four nonprofit land trusts. While nonprofit land trusts may be an effective measure for preserving land for community gardens, they are generally dependent upon funding by grants, foundations, and private donations. Land trusts may not be ideal for community gardening groups which do not have access to these resources. For these groups, knowledge of urban space policies, how to effect change, and partnerships with local government might be seen as measures for preserving land.

A study by the Green Communities division of Parks \& People Foundation of Baltimore sought to offer a "road map" for ways in which community gardeners and community garden supporters could assess the open space policy in their cities in an effort to help formulate plans and action for formal city policy or municipal code (Kirschbaum, 2000). The study looked at open space policies and procedures in Baltimore and six other cities with similar demographic and socioeconomic profiles. Researchers focused specifically on small neighborhood green spaces and sought to develop a comprehensive strategy for Baltimore. In order to determine how small green spaces are currently managed, researchers looked at Baltimore and six other cities' approaches to city- and community-managed open spaces and vacant lots, tax and lien abatements, options for private ownership, government and nonprofit urban gardening programs, and land trusts/land banking (Kirschbaum, 2000).

An important finding of the study dealt with what successful management of open spaces looks like. A key ingredient for the successful management is:

a strong partnership among three primary groups: grassroots organizations, most often community gardening groups . . . technical assistance groups, usually nonprofits that provide support to the gardening groups ... and urban land trusts that lend stability to projects by acquiring title to the properties, thus protecting them from the immediate 
pressures of development and in many cases preserving the sites in perpetuity. (quoted in Kirschbaum, 2000)

In addition other key elements for successful management included an overall city space plan or strategy and a "strong partnership between local government and the other groups (generally nonprofits) participating in the process" (quoted in Kirschbaum, 2000). The study concluded that community participation and local government support are critical to the successful management of community open spaces. The study offered a number of recommendations for the city of Baltimore, including:

- creating an open space council with diverse representation of public and private groups and citizens

- mounting an "awareness" campaign

- revising city and state policies and procedures to make it easier to reclaim vacant land, manage city-owned land, and diversify management of vacant land

- instituting an independent, urban land trust to preserve established open spaces and provide insurance and guidance (Kirschbaum, 2000)

Establishing partnerships between public planning departments and community gardening organizations

This section reports the findings of a study by Herbach (1998), in which he sought to establish the extent to which community gardening organizations meet some of the planning functions (such as improvement of human settlements, a focus on the future, and open participation in decision making) addressed by public planners. Herbach sought to establish a connection between the work of public planners and that of community gardening organizations. If community gardening organizations do indeed work to achieve some of the goals of public planners, Herbach postulated, then perhaps partnerships and a support system could be created between the two groups. Herbach (1998) states,

planners could help protect community gardens by working to get the gardens onto city land use maps, by helping them become part of zoning ordinances, by creating policies 
and plans that support the creation of community gardens and by helping to secure acquisition monies for new community garden sites. (4)

Herbach's study consisted of two phases. In the first phase, he contacted community gardening organizations from around the country and asked them for materials explaining their programs and their mission statements. In the second phase, he chose 16 community gardening programs and sent them a survey, based on work by the American Collegiate Schools of Planning, asking participants whether or not they fulfilled a variety of planning-like functions. (For a more detailed explanation of survey methods, see the Methods section in this study. The survey Herbach used can be found in Appendix D).

Herbach found that results from phase one of the study supported his initial assumptions about the planning-like functions gardening organizations play. Herbach chose to study the results of 18 of the gardening organizations which responded to his request for materials. Those 18 organizations met his criteria for being part of the exploration, as they "had the facilitation of community gardening as one of their major functions and they were associated with more than one garden" (Herbach, 1998: 16). He found that each of the 18 organizations was trying to create the planning-like benefits that can accompany community gardening. The organizations' mission statements included goals such as empowering people through job skills, creating businesses, beautifying neighborhoods, and creating meaningful interaction with the community. Most organizations also included educational outreach as part of their mission statement and many had programs designed to address urban poverty and food security.

Results from phase two of the study, in which 16 gardening organizations were chosen to answer a survey questioning them specifically about a variety of planning-like functions, showed that the gardening organizations fulfill many of the planning-like functions of public planners. Fifteen of the 16 organizations said they work to improve the neighborhood adjacent to the garden and work to deal with urban problems. Thirteen of the 16 organizations have programs that "link community gardening to the development of business, job skills or housing in garden neighborhoods" (Herbach, 1998: 48). Fourteen of the 16 gardening organizations were involved 
in educational outreach and worked specifically with schools. Eleven of the 16 groups said they deal with environmental issues. Most of the organizations linked their work with the work of other nonprofit organizations, businesses, or governments. Eleven of the 16 had some link to government and worked with businesses. All of the organizations said they work with nonprofit organizations. Fifteen of the 16 organizations said they have programs designed to improve access to gardens for disadvantaged people.

While the gardening organizations appear to be addressing many of the planning functions of public planners, one category, creating plans for organizational change and new garden sites, received fairly low affirmative responses. Only four of the 16 organizations surveyed said they do "community garden planning in the sense of preparing citywide plans for introduction of new gardens where and when they are needed" (Herbach, 1998: 62).

Most of the gardening organizations appear to be committed to democratic processes and encouraging leadership in their gardens. Fifteen of the 16 organizations said gardeners help make decisions about the physical development, rules, and structure of individual gardens. Nine of the 16 organizations brought non-gardening neighbors into the process of garden development and rule-making. Ten of the 16 organizations work to develop local leadership at the gardens. (Herbach, 1998)

Herbach concluded that the community gardening organizations involved in his research address a diverse range of social issues and because of their comprehensiveness are worthy of the support of public planners. Herbach argues that "well-organized community garden organizations have the capacity to alter the lives of people at the neighborhood level in ways that public planning would like to, but cannot easily for a variety of reasons, from politics to staffing." (Herbach, 1998: 70). Public planners could assist community gardening organizations in many ways, including supporting with plans, providing information, and helping build partnerships. In this respect public planners would be fulfilling some of their own goals, while benefiting community gardening organizations as well. 
Herbach recognized several limitations of his study, including the reliability of the survey completed by the gardening organizations. It is difficult to know what the groups actually do, compared with what they say they do, without visiting and observing them and the actual work of the staff members and gardeners.

\section{Summary}

The history of community gardens in America during the past century includes times of enthusiastic support by citizens, government, and private organizations, as well as times of enthusiastic protest to the destruction of gardens due to development pressures and lack of policies that create garden security, and times of gradual waning of community gardens as gardeners move on to other work. Quantitative and qualitative research regarding community gardens has shown that community gardens can provide many benefits both to individual gardens and communities. From their quality-of-life benefits, such as providing social outlets and improving self-esteem, to community building and educational benefits, community gardens are, as Hynes (1996) says, "one of our most participatory local civic institutions, and among the few living landscapes of our cities" (160).

Community garden research has shown how a community garden can benefit gardeners and how garden management varies among national gardening organizations. Research has also provided case studies of community gardening projects from across the nation, showing how community gardening projects have been conceived, planned, and implemented, and the struggles and successes those projects have faced. Of the many avenues for continued community garden research, one is research that connects how a garden's location influences the gardeners' motivations for gardening. While other studies have used garden demographics, such as city size, in making comparisons between gardening organizations, no studies have been constructed looking at the context and influence of a garden's location on gardeners' motivations for gardening. This study seeks to address that issue by comparing two community gardening projects, one in the inner-city of Louisville and the other in suburban Jefferson County. This study uses the survey methods of Waliczek et al. and of Herbach, as well as two surveys 
designed by this researcher, as the researcher looks for commonalities and differences in two community gardening programs, one sponsored by county government and the other sponsored by city government, and the gardeners' motivations for gardening at the inner-city Limerick garden and the suburban Blackacre garden. 


\section{METHOD}

\section{Introduction}

This study was designed to elicit the community gardeners' demographics and motivations for gardening as well as to compare management practices of a county versus city-run community gardening program through the lens of the Blackacre and Limerick Community Gardens. The research involved three groups of populations, one, the community gardeners, two, the community garden managers, and three, the county and city community garden program administrators.

\section{Sample}

The researcher surveyed 16 community gardeners from the Limerick Community Garden, located within a mile of downtown Louisville and 33 community gardeners from the Blackacre Community Garden, located in eastern, suburban Jefferson County, Kentucky. The researcher administered the surveys by attending community garden celebrations, via mail, and by visiting a garden administrator at his home.

The researcher proposed to survey 20 gardeners from both the Blackacre and Limerick gardens in order to provide an informative look at the characteristics and motivations of community gardeners at the Blackacre and Limerick Community Gardens. This study is not designed to identify the characteristics and motivations of every gardener at each garden site nor to be representative of all gardeners in the county and city community gardens. It is beyond the scope of this research to survey all gardeners at both garden sites; rather, it is the aim of the researcher to get a good cross section of gardeners at the two sites, Blackacre and Limerick. It is not surprising that the researcher was able to get more than 20 gardeners from the Blackacre garden to participate in the study, given that the surveys were administered and collected during the Blackacre Community Garden celebration. The 16 responses for the Limerick garden were slightly less than the wished for 20 responses. The researcher hand delivered or mailed a survey to all Limerick community gardeners and was pleased with a response by 16 of the 26 gardeners. 


\section{Surveys}

The researcher used a combination of four surveys for this study; two designed by this researcher (Appendixes A and C), another designed and implemented by Waliczek, Mattson and Zajicek (Appendix B), and a third designed and implemented by Herbach (Appendix D). The Waliczek, Mattson and Zajicek survey and the Herbach survey are validated survey instruments, affording the researcher the opportunity to use methods which have already been validated with community gardeners and community garden organizations.

The researcher administered two of the four surveys, Community Gardener Survey, Parts I and II (Appendixes A and B respectively), to the community gardeners. The remaining two surveys, the Community Garden Manager and County/City Administrator Survey, Parts I and II (Appendixes $\mathrm{C}$ and $\mathrm{D}$ respectively), were administered to the garden managers at the two sites and both the county and city administrator for the community gardening programs.

The researcher administered the surveys to the gardeners and asked them to read the preamble regarding agreement to participate. The researcher informed participants it would take approximately ten minutes or less to complete the survey. The researcher read the survey to one gardener, whose eyesight was poor, and recorded his responses. Incidentally, that gardener is $\mathbf{8 5}$ years old, one of the oldest of the Blackacre gardeners.

\section{Community Gardener Survey - Part I (Appendix A)}

In addition to the validated surveys, the researcher designed a community gardener survey to elicit basic demographic information about the gardeners, such as age, gender, ethnicity, and income (questions 3-6). The survey was designed to help establish a picture of who the gardeners are and determine if a typical profile exists for an inner city versus suburban gardener in Jefferson County. Questions 1 and 2 ask the gardeners for information regarding years of gardening experience and number of years they have gardened at the community garden. Questions 7 concerns the distance the gardener lives from the garden. This question was designed to help establish how far the gardeners travel to the garden. It was hypothesized that the inner city gardeners live less than one mile from the site, while the suburban gardeners may 
travel a good distance to the garden. The distance the gardeners travel to the garden is significant because it may influence garden management, amount of time spent in the garden per week, and motivation for gardening. Questions 8 and 9 concern the amount of time gardeners spend per week at the garden. Questions 10 and 11 concern what kinds of plants gardeners grow and uses for the food grown. Questions 12 and 13 ask the gardener his or her reasons for gardening and reasons for gardening at the Blackacre or Limerick Community Garden. Question 14 asks the gardener what he or she learns from gardening.

Community Gardener Survey - Part II (Appendix B)

The second survey, designed by Waliczek, Mattson, and Zajicek, was designed to "question individuals on garden benefits and their influence on gardeners' perceptions of quality-of-life" (Waliczek, Mattson, and Zajicek, 1996: 205) (Appendix B). The survey is a list of 24 statements following a format by Kaplan et. al., and written to test quality-of-life factors which are based on Maslow's hierarchy of human needs. The statements progress from physiological and safety needs (statements 1-8), to social needs (statements 9-15), to esteem and self-actualization needs (statements 16-24). In addition, there is a twenty-fifth statement created by this researcher designed to assess food security needs.

Community Garden Manager and County/City Administrator Survey - Part I (Appendix C)

The third survey, designed by this researcher, contains 17 questions designed to elicit garden demographics and management practices from the garden manager and county or city administrator. Questions 1 through 3 ask when the garden was established, how it was started and by whom it was organized and how it was determined there was a need for the garden. Question 4 asks how the garden location was determined. The landowner of the garden site and the size of the garden are reflected in Questions 5 and 6. Questions 7, 8 and 9 concern whether the garden is made up of individual or communal plots, number of gardeners at the site, and who the gardeners are. Question 10 asks about the role of the garden manager and county/city administrator. Questions 11 through 17 relate to garden preparation and administration. Questions 11 through 14 relate to who prepares the land, what role gardeners play in site 
preparation, whether a fee exists for gardening and what the application process is for gardening. Questions 15 and 16 relate to whether there are written rules, which must be agreed to, and kinds of supplies the county or city provides. Question 17 asks whether the garden has any celebratory activities and who plans them.

Community Garden Manager and County/City Administrator Survey - Part II (Appendix D)

The fourth survey, designed by Herbach, contains 18 questions designed to assess the planning function of community gardening organizations (Appendix $\mathrm{C}$ ). This survey was administered to the two garden managers and the two garden administrators at the county and city level. This survey was used to identify the gardening organization's relationship to the community and to help establish basic commonalities and differences in the management practices of the county and city organizations. The survey participants were asked to respond 'yes' or 'no' to the eighteen questions, indicating whether or not their gardening organization does indeed work to meet the needs indicated in the questions.

Geoffrey Herbach designed and reported the results of the survey in his research, "Community Gardening Organizations' Relationship to the Public Planning Function: A Story of Shared Goals," in 1998 as part of his Master of Science in Urban and Regional Planning from the University of Wisconsin-Madison. Herbach designed the survey based on work by the Strategic Marketing Committee of the Association of Collegiate Schools of Planning (ACSP). The ACSP Committee created six anchor points for identifying good planning practice. Herbach created his survey based upon these anchor points. Following are the six anchor points and the survey questions, which relate to them:

(I) a focus on improvement of human settlements with emphasis on understanding cities, suburbs, small places and regions including processes of physical development and their changing social and economic characteristics and emphasis on making places better serve the needs of people, including solving perceived urban problems.

Questions 1 and 2 relate to anchor point I. (1) Does your organization work to improve the social and physical environments of the neighborhoods in which your gardens are located? (2) 
Does your organization address urban problems, 2a. joblessness, $2 \mathrm{~b}$. drug abuse, $2 \mathrm{c}$. vandalism, 2d. other?

(II) a focus on interconnections among distinct community facets, incorporating the following: linkages among physical, economic, natural, and social dimensions, linkages among sectors such as transportation and land use, housing and economic development, and linkages between public and private enterprises.

Questions 3, 4, 5, 6 and 7 relate to anchor point II. (3) Does your organization offer programs that teach gardeners to market products of the gardens in stores, at farmers' markets, at restaurants, or through another outlet? (4) Does your organization link the development of gardens with the development of $4 a$. housing, $4 \mathrm{~b}$. local businesses? (5) Does your organization work with schools to run youth educational programs in community or school gardens? (6) Does your organization deal with environmental sustainability in any of its programs or in its mission statement? (7) Does your organization work on projects in partnership with 7a. businesses, $7 \mathrm{~b}$. government, $7 \mathrm{c}$. non profit organizations?

(111) a focus on the future and pathways of change over time, encompassing affirmation of community goals and aspirations, forecasting probably or feasible paths, developing plans to achieve desired futures and understanding the historical momentum shaping the present and future.

Questions 8, 9 and 10 relate to anchor point III. (8) Have you created a written plan for organizational growth? (9) Have you created a written plan for the development of new gardens and garden related programs based on perceived demographic or economic change occurring in your city? (10) Do you have specific programs meant to work with people affected by welfare reform?

(IV) a focus on identification of the diversity of needs and distributional consequences in human settlements, guided by concern for public well-being, monitoring changing population, targeting needs of all segments in the population and developing rationales for equitable distribution of community benefits. 
Questions 11 and 12 relate to anchor point IV. (11) Does your organization provide access for handicapped gardeners? (12) Does your organization do outreach work to minority groups?

(V) a focus on open participation in decision making, including citizen participation, stakeholder representation, negotiation and mutual compromise among competing interests, dispute resolution, communication of technical facts in lay terms and recognizing value-centrism embedded in analysis and prescription.

Questions 13,14, 15 and 16 relate to anchor point V. (13) Do the organization's gardeners have a say in the organization's direction? (14) Do gardeners have a say in decisions made at their particular garden sites? (15) Is there a plan to develop leadership and organization at individual garden site? (16) Are non-gardening interests in the communities your organization serves involved in the decision making for sites in their (the non-gardening interests') neighborhoods?

(VI) a focus on linking knowledge and collective action, recognizing that planning bridges academic knowledge and professional practice, information flows across the bridge both ways, linking the university to the "real world," planning practice is enhanced by infusion of humanities, social science, and technical knowledge and academic knowledge is enhanced by confrontation with experience in practice.

Questions 17 and 18 relate to anchor point VI. (17) Does staff and/or students from a local college or university work with your organization? (18) Does county extension staff work with your organization? (Herbach, 21-30)

The survey participants were asked to respond 'yes' or 'no' to the eighteen questions. Herbach surveyed sixteen community gardening organizations nationwide. His findings are reviewed in the Review of Literature section of this study.

\section{Procedures}

On August 31, 2000 the researcher attended the Community Garden Harvest Celebration sponsored by the City of Louisville's Department of Neighorhoods and Operation Brightside for the city-run community gardening program. In attendance at the celebration were community gardeners from the five city community gardens and one community garden which 
was established in partnership with the Department of Neighborhoods. The researcher invited community gardeners to participate in the study. The researcher received completed surveys from four Limerick community gardeners who were in attendance at the celebration. The Limerick garden manager took three surveys and gave them to her neighbors who garden at Limerick, and they returned the surveys to the researcher via mail. The researcher then contacted the Limerick garden manager and received the names and addresses for the remaining gardeners. The researcher mailed 18 surveys along with a letter inviting gardeners to participate in the study and a self-addressed stamped envelope for the return of the survey. Of the 18 surveys mailed to the gardeners, nine Limerick gardeners responded. The total number of Limerick gardeners participating in the study was 16 out of a total of 26 Limerick gardeners.

The researcher gathered the Blackacre Community Garden data on two occasions. On August 23, 2000, during a visit to the Blackacre Community Garden the researcher met with the garden manager and five gardeners who agreed to participate in the study. On September 16, 2000, the researcher attended the annual Blackacre Community Garden Celebration, a pot-luck picnic attended by more than 40 gardeners and their families. The researcher invited gardeners to participate in the study. The total number of Blackacre community gardeners who completed surveys is 33 out of an estimated 200 gardeners.

The researcher administered the surveys to the community garden managers and the county and city administrators in the following manners: the researcher hand delivered the survey to the city garden manager during the city community garden celebration and e-mailed the survey to the city garden administrator; the researcher hand delivered the survey to the county garden manager during a visit to the Blackacre Community Garden and visited the county garden administrator at his home in order to complete the survey. The participants then hand delivered the survey to the researcher or mailed it. 


\section{Data Analysis}

Community Gardener Survey - Part I

The researcher compared categorical responses to questions one through nine and 11 using descriptive statistics. Descriptive statistics were used to provide an overview of who the gardeners are at the two garden sites.

Results for question six, "Which category describes your income?" were not included in the Findings section. The researcher found this question too problematic to include the results in the study. The question did not clarify whether the participant should indicate his or her personal income or family income. The researcher feels the results for this question would not provide an accurate picture of gardeners' income.

The Community Gardener Survey, Part I, contains open-ended questions for numbers 10, 12,13 and 14. The researcher anticipated the gardeners' responses to these questions could be categorized. The researcher compared the participants' responses based on the following categories and found that several new categories were needed.

The responses to question 10, "What kinds of plants do you grow?," were grouped into the following categories: Flowers, Vegetables, Herbs or a combination. The only new category which was needed for this question was "other" as a few gardeners grew fruits, such as blackberries, in addition to vegetables and/or herbs

It was anticipated the responses to question 12, "Why do you garden?" would be grouped into the following categories: (1) Social connections, (2) For health/exercise, (3) Enjoy working with soil, plants and nature, and (4) For nutritional needs. These categories were not sufficient to contain the gardeners' responses. Categories (1), (2), and (3) remained the same, however, category (4) was changed to "For home-grown/fresh food" as many of the responses better reflected this reason for gardening compared with "For nutritional needs." Five new categories were added, including: "Hobby, pastime, fun," "To save money," "For feeling of satisfaction/accomplishment," "Connection with the past," and "To help a soup kitchen." 
It was anticipated the responses to question 13, "Why do you garden at the Blackacre or Limerick Community Garden?" would be grouped into the following categories:

(1)Accessibility/location/convenience, (2) Social Connections, and (3) Community

Development. These categories alone did not meet the responses for why gardeners garden at the Blackacre or Limerick Community Gardens. The following categories were created to reflect the other responses given by gardeners, "Security," "Limited garden space at home," "Well-managed," "Good quality soil," "For the vegetables and homegrown items," and "Transferred from the LaGrange Road garden."

It was anticipated the responses to question 14, "What do you learn from gardening?" would be grouped into the following categories: (1) Self-improvement, (2) Caring for nature, and (3) Caring for community. While these categories did fit the majority of the gardeners' responses, two new categories were added and one category was changed to better reflect the gardeners' responses. Category (2) Caring for nature, was changed to "Ecology, Reverence for nature, gardening techniques" to better reflect the responses. The two new categories were "Reverence for God" and "Greater respect for farmers." While some people might consider reverence for nature and reverence for God to be synonymous, the researcher did not want to make this assumption. Rather, if a gardener specifically stated that he or she learned to "commune with God," or "the goodness of God," the category "Reverence for God" was selected.

\section{Community Gardener Survey - Part II}

Descriptive statistics were used to compare categorical responses for Part II of the Community Gardener Survey. Both the means and the modes were compared for all gardeners at the Blackacre and Limerick Community Gardens.

\section{Community Garden Manager and County/City Administrator Survey, Part I}

The researcher used the responses from Part I of this survey to give an overview of the two gardens, laying a foundation for understanding how the gardens were established, their rules 
and regulations, and similarities and differences in the management practices of the city and county gardening programs.

\section{Community Garden Manager and County/City Administrator Survey, Part II}

The data collected from Part II of this survey was analyzed to determine whether the gardening organizations address some of the goals of public planning departments, as well as to identify the gardening organization's relationship to the community. The survey was also used to help establish basic commonalities and differences in the management practices of the county and city organizations which oversee the gardening programs. The method for analyzing the data was created by Herbach in his study, "Community Gardening Organizations' Relationship to the Public Planning Function: A Story of Shared Goals" (1998).

The eighteen questions in Part II of the Community Garden Manager and County/City Administrator Survey were grouped into ten planning categories, which were based on the Association of Collegiate Schools of Planning's Anchor Points for Planning's Identification (see pages 38-40). The ten categories, the anchor points from which they were drawn and the survey questions to which they correspond are as follows:

(1) Improving the neighborhood adjacent to the garden (From Anchor Point I, Represented by question 1).

(2) Dealing with urban problems (From Anchor Point I, Represented by question 2a, 2b, 2c, and 2d).

(3) Doing community development projects such as business development and housing development (From Anchor Point II, Represented by questions 3 and 4).

(4) Creating education programs (From Anchor Point II, Represented by question 5).

(5) Dealing with environmental issues (From Anchor Point II, Represented by question 6)

(6) Linking programs with the work of other nonprofit groups, businesses, government (From Anchor Point II, Represented by question 7a, 7b and 7c).

(7) Creating plans for organizational change and new garden sites (From Anchor Point III, Represented by questions 8 and 9 ). 
(8) Providing outreach and access to gardens for disadvantaged groups (From Anchor Point IV, Represented by questions 10,11 and 12 ).

(9) Encouraging Democratic processes and local leadership (From Anchor Point V, Represented by questions $13,14,15$ and 16 ).

(10) Linking academic knowledge with on the ground activities (From Anchor Point VI, Represented by questions 17 and 18).

The researcher looked at the responses to all eighteen questions and then looked for the presence of a 'yes' response to any of the questions in the ten planning categories. The presence of a 'yes' in the ten planning categories indicated that the gardening organization does work to meet some aspect of that category.

The researcher anticipated that the Blackacre and Limerick garden managers' perspectives on the gardens' relationship to the community and garden management would differ from that of the organization administrators' perspective given that the two work in different arenas, with the administrators more closely connected with the government program sponsoring the gardens. Perhaps the garden administrators would view their organizations as meeting more of the planning categories than the garden managers because they see their gardening organization as part of a larger organization they work for; i.e. the Department of Neighborhoods for the city and the Office of Community Outreach for the county.

The researcher also anticipated that the Limerick garden manager's responses would differ more significantly from the Limerick garden administrator's responses than the Blackacre garden manager's responses would differ from the Blackacre garden administrator's responses. The reasons for this expectation is that the Limerick garden manager is a volunteer, who is less affiliated with the city government than the Blackacre garden manager who is in a paid position with the county's Office of Community Outreach. Responses to this survey, then, are compared both between the two gardens and between the manager and administrator for both gardens. 


\section{FINDINGS}

\section{Introduction}

The following are the results from the Community Garden Manager and County/City Administrator Survey, Parts I and II and from the Community Gardener Survey, Parts I and II.

\section{Qverview of the Blackacre and Limerick Community Gardens}

The following overview is based on the responses to the Community Garden Manager and County/City Administrator Survey, Part I completed by the community garden managers and the community garden administrators for both the Blackacre and Limerick Community Gardens. Establishing a need for the gardens

The Limerick garden appears to have been established because there was sufficient community interest, and it would provide garden space for nearby residents, many of whom lived in apartments or otherwise lacked land on which to garden. The Limerick garden was established on a parking lot owned by the nearby housing complex, The Chapel House. According to the Limerick garden manager, reclamation of an urban eyesore could have been one reason for establishing the garden. She states that perhaps the "availability of an unsightly parking lot next to an abandoned cleaners" helped establish a need for the garden.

The Blackacre garden was established as a result of the loss of a community garden on LaGrange Road. The county-owned land on which the LaGrange Road garden was located was sold, leaving the Office of Community Outreach, which oversees the county community gardening program, to search for a new garden location. The county government sought a good location to establish a new community garden and found it at the Blackacre State Nature Preserve, which is located in eastern Jefferson County, nearby Taylorsville Road and the Gene Snyder Freeway. The new location would provide easy access for gardeners and was beautiful, flat land. Many of the gardeners who gardened at the LaGrange Road garden transferred to the Blackacre garden once it was established. According to the Blackacre garden manager, the Blackacre garden was established in response to the needs of senior citizens who are "looking for something to do, such as exercise, therapy and new friends." The community garden can 
help fulfill those needs and is a "wonderful program for socializing," according to the Blackacre garden manager. In response to the question, "How was it determined there was a need for the garden?", the county community garden administrator responded, "We (the county) knew from experience. It (the garden) is better than any medication a doctor could give seniors. The gardening program is essential for seniors." He also referred to the value of the garden in "keeping your mind occupied" and providing an outlet for exercise and social connections. Garden size

The Blackacre and Limerick Community Gardens are quite different in terms of garden size, with the Limerick garden resting on a parking lot of just a couple of acres, while the Blackacre garden lies on approximately 30 acres of land. Individual garden plots are ten feet wide by 20 feet long at the Limerick garden and 30 feet wide by 30 feet long at the Blackacre garden.

\section{Limerick Community Garden}

One of the oldest City of Louisville-sponsored community gardens, the Limerick Community Garden was first established in 1986 as a partnership between the City of Louisville, Operation Brightside, and the Limerick Neighborhood Association. According to the Limerick garden manager, a core group of volunteers helped establish the garden.

This practice of grassroots involvement is an essential component of the city gardening program. The responsibility for the initiative to start a community garden rests in the hands of the residents of the City of Louisville. A core group of volunteers can either start a community garden on privately owned land or locate a city-owned parcel of vacant land and agree to lease it for a nominal fee. At least one person must be willing to take responsibility for the garden site. If the city owns the land, that person, who becomes the garden's site coordinator or manager, must sign an Agreement for Use of City Property for Garden and Open Space form. In the case of the Limerick Community Garden, the land on which the garden is located is privately owned by the nearby Chapel House, Inc. and the position of site coordinator changes according to who is willing to take on the responsibilities. The responsibilities of the community garden manager 
or site coordinator include leading/organizing shared garden work days, keeping track of garden tools, reporting weedy plots or conflicts to the city, and serving as a link between the gardeners and the city. In addition, the Limerick garden manager responded that she is responsible for organizing a planning committee to help plan events throughout the year, oversee maintenance of common beds, encourage gardeners to take ownership of certain chores, and "encourage team gardening spirit and getting to know each other."

Once a partnership has been made between the garden start-up group and the city, the city, through the Department of Neighborhoods, will provide additional resources to help make the garden a success. In the case of the Limerick Garden, for example, the city provides water, tools, compost, starter vegetables and seeds, and refreshments on work days and for other events. In addition, the city sends out a community garden newsletter, offers horticultural expertise and tills the gardens upon request. In exchange for the resources provided by the city, the gardeners must apply through the city for a garden plot and must agree to certain rules and regulations. At the Limerick garden, for example, gardeners pay $\$ 15$ to garden and are responsible for maintaining their plots, adjacent paths and common flower beds parallel to their plot. Most of the other city community gardens are free to the gardeners. If certain rules, such as weeding or maintaining garden plots, are not adhered to, the gardener will receive two warnings, after which time the gardener will be informed he or she has lost gardening privileges.

\section{Blackacre Community Garden}

While the Limerick Community Garden is one of the oldest City of Louisville sponsored community gardens, the Blackacre Community Garden is one of the newest Jefferson County sponsored community gardens, established in 1998 on land located at the Blackacre State Nature Preserve.

The Blackacre Community Garden is part of a unique partnership between county government, a private foundation, a public school system and a state conservation program. The land on which the garden is located was purchased by the Blackacre Foundation and lies next to the Blackacre State Nature Preserve, a unique state nature preserve. Not only is the Blackacre 
State Nature Preserve the oldest state nature preserve, its management is unique in that it is a partnership between the Jefferson County Public Schools, the Kentucky State Nature Preserves Commission and the Blackacre Foundation. In addition to setting aside land as a home for plants and animals, Blackacre is used as an educational setting for Jefferson County students, is a home to one of the oldest settlements in Jefferson County with buildings and a barn dating from the late 1700 's, and is now a partner with a community garden effort. The Jefferson County government leases the land on which the garden is located for $\$ 2500$ per year from the Blackacre Foundation. The county government's gardening program manages three other community gardens, two of which are county-owned while the third is also leased.

While the Limerick Community Garden and other city sponsored gardens are a grassroots effort, the county sponsored gardens are more of a top-down approach, with management coming from the county government and responsibilities filtering down to the gardeners. Whereas the Limerick garden has a volunteer garden manager, the Blackacre garden has a paid manager who works four days a week from eight a.m. to four p.m. Blackacre's garden manager's responsibilities include collecting monies for the plots and turning them in to the county government, assigning gardeners to their plots and enforcing the rules of the gardening contract (signed by all gardeners). In addition, Blackacre's garden manager gives out plants to the gardeners, rents tillers, monitors planting, acquires supplies, such as mulch, lime and manure, and monitors safety rules. The Blackacre garden manager works out of a trailer located at the garden, while the Limerick garden manager either completes paperwork at home or on a picnic table at the garden. The trailer at the Blackacre Community Garden serves not only as a work place for the garden manager, but also as a social gathering place for the manager and the community gardeners who often gather there to talk and eat.

The county gardening program is similar to the city sponsored community gardening program in its approach to gardener responsibilities. Blackacre community gardeners must sign up to participate in the gardening program and must sign a rules and regulations form. As with the city gardening program, the county gardening program gives priority to gardeners who have 
had plots in the previous year. After those gardeners choose their garden plots, other gardeners are assigned on a "first come, first served" basis. The cost to garden at any of the county's community gardens is $\$ 5$ for persons 50 years or older and $\$ 30$ for persons under age 50 or two plots for $\$ 50$. Just as the city gardening program provides the gardeners with resources to make the garden season a success, the county provides such amenities as gardening tools, water, compost, lime, wood chips, and starter vegetables and seeds.

Fundamental differences in management of the gardens

An important distinction to make between the county and city gardening programs is that the county community gardening program is specifically geared towards meeting the needs of senior citizens, although persons of any age may garden, while the city gardening program is open to anyone who wishes to participate at existing garden sites (given availability) or work to establish a new one. The Jefferson County Office of Community Outreach runs the county community gardening program through the Senior Citizens Activities Coordinator (referred to in this study as the county community garden administrator), an 82 year old go-getter who works full time, loves his job, and doesn't plan on stopping any time soon. His responsibilities include overseeing the community gardening program, working with the garden managers and the garden councils, made up of four or five gardeners from each garden, and visiting the gardens to help with any problems that may arise. The county community garden administrator considers himself an ombudsman for the seniors and the gardening program, working to meet the needs of those involved.

The approach of running a community gardening program through a senior citizens' program is very different from the city's approach. The City of Louisville's Department of Neighborhoods manages the city community gardening program through its Coordinator of Landscape (referred to in this study as the city community garden administrator), a twenty-something gardening enthusiast who has a degreein horticulture and loves to work with the community gardeners. Her responsibilities include overseeing the community gardening 
program which includes working with various city departments, scheduling contractors and coordinating volunteers. She also works to educate gardeners about horticulture techniques.

\section{Planning-type work of the Blackacre and Limerick gardening organizations}

The following results are based on responses to the Community Garden Manager and County/City Administrator Survey, Part II.

The participants were asked to answer 'yes' or 'no' to the eighteen questions on the survey. For the complete list of questions see Appendix D. The eighteen questions from the survey were grouped into ten planning categories (for rationale and questions that represent the categories, see Method section). Table 3-10 contains the ten planning categories and whether or not the garden manager and administrator from both the Blackacre and Limerick Community Gardens said they work to fulfill those planning functions. A ' 1 ' indicates that 'yes' the gardening organization does work to fulfill the planning functions, while a ' 0 ' indicates that 'no' the gardening organization does not work to fulfill the planning functions.

An initial look at the data indicates that the two gardening organizations which oversee the Blackacre and Limerick community gardens do work to fulfill a majority of the planning categories, according to three of the survey participants: the Blackacre garden manager, the Blackacre garden administrator, and the Limerick garden administrator. The responses of the fourth survey participant, the Limerick garden manager, are in stark contrast to the Limerick garden administrator's responses and reveal that the Limerick garden manager does not perceive her gardening organization as fulfilling very many of the planning categories (only four of ten).

For both the Blackacre and Limerick Community Gardens, the garden administrators answered affirmatively to more of the survey questions than did the garden managers, indicating that the garden administrators perceive their organization as being more diverse than do the garden managers. Specifically, the Blackacre garden administrator's responses indicated that his organization, the Office of Community Outreach, a division of Jefferson County government, works to fulfill nine of the ten planning categories, while the Blackacre garden manager's responses indicated the gardening organization works to fulfill seven of the ten categories. The 
Limerick garden administrator's responses indicated that her organization, the Department of Neighborhoods, works to fulfill all ten of the planning categories, while the Limerick garden manager's responses indicated the gardening organization works to fulfill only four of the ten planning categories.

\section{Limerick garden}

The planning categories in which the Limerick garden manager and administrator were in agreement regarding the work of their organization were (2) "Dealing with urban problems," (5) "Dealing with environmental issues," (8) "Providing outreach and access to gardens for disadvantaged groups," and (9) "Encouraging democratic processes and local leadership."

Planning category (2) Dealing with urban problems contains question number (2) "Does your organization address urban problems, 2a. Joblessness?, 2b. Drug abuse?, 2c. Vandalism?, 2d. Others?" The Limerick garden manager answered affirmatively only to 2c. Vandalism, while the Limerick garden administrator answered affirmatively to $2 b$. Drug abuse, $2 c$. Vandalism, and 2d. Others, to which she listed "Blockwatch."

Planning category (5) "Dealing with environmental issues" contains question number (6) "Does your organization deal with environmental sustainability in any of its programs or in its mission statement?" Both the Limerick garden manager and administrator were in agreement that their organization does deal with environmental sustainability.

Planning category (8) "Providing outreach and access to gardens for disadvantaged groups" contains questions numbered (10) "Do you have specific programs meant to work with people affected by welfare reform?," (11) "Does your organization provide access for handicapped gardeners?," and (12) "Does your organization do outreach work to minority groups?" The Limerick garden manager answered affirmatively only to question 11, replying that the garden has two raised beds accessible by wheelchairs and short handled tools available. In addition, the Limerick garden manager responded "no"sto question 12, but said the garden does have some diversity with "three black and one Asian gardener." The Limerick garden administrator answered affirmatively to all three questions for category (8). 
Planning category (9) "Encouraging democratic processes and local leadership" contains questions numbered (13) “Do the organizations gardeners have a say in the organization's direction?," (14) "Do gardeners have a say in decision made at their particular garden sites?," (15) "Is there a plan to develop leadership and organization at individual garden sites?" and (16) "Are non-gardening interests in the communities your organization serves involved in the decision making for sites in their (the non-gardening interests') neighborhoods?" The Limerick garden manager answered affirmatively to questions (13) and (14), while the Limerick garden administrator answered affirmatively to questions (14), (15), and (16).

Blackacre garden

As the Blackacre garden manager and administrator's agreed in seven out of ten planning categories (1), (2), (4), (5), (8), (9), and (10), that their organization is working to fulfill those needs, and also agreed in one of the ten planning categories, (3), that their organization is not working to fulfill that need, only the categories in which they were in disagreement will be highlighted. Those categories were (6) "Linking programs with work of other non-profit organizations, businesses, government," and (7) "Creating plans for organizational change and new garden sites."

Category (6) contains question number (7) "Does your organization work on projects in partnership with 7a. Businesses, 7b. Government, 7c. Non-profit organizations?" The Blackacre garden manager responded "no" to all three sections of question (7), while the Blackacre garden administrator responded "yes" to all three sections. The researcher is unsure how to explain the garden manager's responses, because it is clear the Blackacre Community Garden and the Office of Community Outreach do work in partnerships with those entities. For example, businesses donate seeds and supplies for events at the Blackacre garden, the county government is the supporting structure for the garden, and a non-profit organization, the Blackacre Foundation, is a strong partner of the garden, owning the land on which it is located. Perhaps the garden manager misinterpreted the question. 
Category (7) contains questions numbered (8) "Has your organization created a written plan for organizational growth?," and (9) "Has your organization created a written plan for the development of new gardens and garden related programs based on perceived demographic or economic change occurring in your city?" The Blackacre garden manager had no response for both questions, indicating she may not know whether the organization has done those things, while the Blackacre garden administrator responded "yes" to both questions. If either the manager or administrator would know if a plan had been created, it makes sense that the administrator, one higher up in the organization, would know.

Table 1: Planning categories addressed by the city and county gardening programs

\begin{tabular}{|c|l|c|c|c|c|}
\hline & \multicolumn{2}{|c|}{ Blackacre Garden } & \multicolumn{2}{c|}{ Limerick Garden } \\
\hline & Planning category & Manager & Administrator & Manager & Administrator \\
\hline 1 & 1 & 1 & 0 & 1 \\
\hline 2 & $\begin{array}{l}\text { Improving neighborhoods } \\
\text { adjacent to garden }\end{array}$ & 1 & 1 & 1 & 1 \\
\hline 2 & Dealing with urban problems & 0 & 0 & 0 & 1 \\
\hline 3 & Doing community development & 0 & 1 & 0 & 1 \\
\hline 4 & Creating educational programs & 1 & 1 & 0 & 1 \\
\hline 5 & $\begin{array}{l}\text { Dealing with environmental } \\
\text { issues }\end{array}$ & 1 & 1 & 0 & 1 \\
\hline 6 & $\begin{array}{l}\text { Linking programs with work of } \\
\text { other non-profit organizations, } \\
\text { businesses, government }\end{array}$ & 0 & 1 & 1 & 1 \\
\hline 7 & $\begin{array}{l}\text { Creating plans for organization- } \\
\text { al change and new garden sites }\end{array}$ & No response & 1 & 1 & 1 \\
\hline 8 & $\begin{array}{l}\text { Providing outreach and access } \\
\text { to gardens for disadvantaged } \\
\text { groups }\end{array}$ & 1 & 1 & 0 & 1 \\
\hline $9 \begin{array}{l}\text { Encouraging democratic } \\
\text { processes and local leadership }\end{array}$ & 1 & $\mathbf{9}$ & 4 & 10 \\
\hline 10 & $\begin{array}{l}\text { inking academic knowledge } \\
\text { with on the ground activities } \\
\text { Totals }\end{array}$ & 7 & 1 & 1 & 1 \\
\hline
\end{tabular}

\section{Community Gardener Survey - Part I}

The following results are based on responses to the Community Gardener Survey, Part I by the Blackacre and Limerick community gardeners who participated in the study. 
Demographics of the community gardeners

The Blackacre Community Garden and the Limerick Community Garden contrast greatly in terms of size of gardener population. While the Blackacre garden had approximately 200 gardeners this season, the Limerick garden had 26 gardeners, according to the Limerick garden administrator. Of those gardeners, 33 Blackacre gardeners and 16 Limerick gardeners completed the Community Gardener Survey, Parts I and II. While the size of the garden populations contrasts, the ethnicity of the gardeners at the two gardens is quite homogeneous. Of the 49 gardeners surveyed at both gardens, 47 (95.9\%) gardeners categorized themselves as white, while two (4\%) gardeners categorized themselves as African-American.

Table 2 reports the age range and gender of participants from the two gardens. The Blackacre gardeners who participated in the study are 32 white and 1 African-American adults, the majority of whom, $22(66.7 \%)$ gardeners, are in the age category of 61 or older. Fifteen of the gardeners age 61 or older are male and seven are female. Eight $(24.2 \%)$ of the gardeners are in the age category of $46-60$ with four males and four females, while the remaining three (9\%) gardeners are in the age category of $31-45$ with one male and two females. There are no gardeners in the Blackacre Community Garden sample under the age of 31 . Overall, $20(60.6 \%)$ males and 13 (39.4\%) females make up the Blackacre Community Garden sample.

The Limerick gardeners who participated in the study are 15 white and one African-American adults, the majority of whom, ten (62.5\%) gardeners, are in the age category of 61 or older. Four of the gardeners in the age category of 61 or older are male and six are female. Two (12.5\%) gardeners, one male and one female, are in the age category of $26-60$, three $(18.8 \%)$ gardeners, one male and two female, are in the age category of $31-45$, and one $(6.3 \%)$ gardener, a male, is in the age category of 21-30. There are no gardeners in the Limerick Community Garden sample under the age of 20 . Overall, seven (43.8\%) males and nine (56.3\%) females make up the Limerick Community Garden sample. 
Table 2: Age of community gardeners surveyed.

\begin{tabular}{|l|c|c|c|c|c|c|}
\hline & \multicolumn{3}{|c|}{ Blackacre Gardeners } & \multicolumn{3}{c|}{ Limerick Gardeners } \\
\hline & Male & Female & Total & Male & Female & Total \\
\hline Under 20 & 0 & 0 & 0 & 0 & 0 & 0 \\
\hline $21-30$ & 0 & 0 & 0 & $1(6.3 \%)$ & 0 & $1(6.3 \%)$ \\
\hline $31-45$ & $1(3 \%)$ & $2(6.1 \%)$ & $3(9.1 \%)$ & $1(6.3 \%)$ & $2(12.5 \%)$ & $3(18.8 \%)$ \\
\hline $46-60$ & $4(12.1 \%)$ & $4(12.1 \%)$ & $8(24.2 \%)$ & $1(6.3 \%)$ & $1(6.3 \%)$ & $2(12.5 \%)$ \\
\hline 61 or older & $15(45.5 \%)$ & $7(21.2 \%)$ & $22(66.7 \%)$ & $4(25 \%)$ & $6(37.5 \%)$ & $10(62.5 \%)$ \\
\hline Total & $20(60.6 \%)$ & $13(39.4 \%)$ & $33(100 \%)$ & $7(43.8 \%)$ & $9(56.3 \%)$ & $16(100 \%)$ \\
\hline
\end{tabular}

Gardening experience

Table 3 contains the data representing the years of gardening experience by the Blackacre and Limerick gardeners who participated in the survey in relation to their age and gender. The majority of gardeners at both sites are very experienced gardeners, with over 15 years of gardening experience per person. Eighteen (54.5\%) of the 33 Blackacre gardeners and nine (56.3\%) of the 16 Limerick gardeners surveyed have over 15 years of gardening experience. Of the 18 Blackacre gardeners with over 15 years of gardening experience, 15 , four females and 11 males, are 61 years of age or older. The remaining three Blackacre gardeners, one female and two males, with over 15 years of gardening experience are in the age category of 46 - 60 years old. Of the nine Limerick gardeners with over 15 years of gardening experience, eight, five females and three males, are 61 years of age or older. The one other Limerick gardener with over 15 years of gardening experience is a female in the age category of 46 - 60 years old.

Six (18.2\%) Blackacre gardeners and one (6.3\%) Limerick gardener have between ten and 15 years of gardening experience. Of the six Blackacre gardeners with between ten and 15 years of gardening experience, four, three females and one male, are 61 years of age or older. One male Blackacre gardener with between ten and 15 years of gardening experience is between 46 and 60 years old and one female Blackacre gardener with between ten and 15 years of gardening experience is between 31 and 45 years old. The one Limerick gardener with between ten and 15 years of gardening experience is between 46 and 60 years of age. 
Seven (21.2\%) Blackacre gardeners and three (18.8\%) Limerick gardeners have between four and ten years of gardening experience. Of the seven Blackacre gardeners with between four and ten years of gardening experience, three, all males, are age 61 or older, two, both females, are age $46-60$, and two, one male and one female, are in the age category of $31-45$ years old. Of the three Limerick gardeners with between four and 10 years of gardening experience, two, one male and one female, are in the age category of $31-45$ years and one, a male, is in the age category of $21-30$ years.

Two (6.1\%) Blackacre gardeners and one (6.3\%) Limerick gardener have between one and three years of gardening experience. Both of the Blackacre gardeners, one male and one female, with between one and three years of gardening experience are in the age category of 46 60 years old. The one Limerick gardener with between one and three years of gardening experience is a male in the age category of 61 years or older.

No Blackacre gardeners have less than four years of gardening experience. One (6.3\%) Limerick gardener, a female in the age category of $31-45$, has between one and three years of gardening experience. One Limerick gardener did not respond to the question. 
Table 3: Years of gardening experience in relation to age and gender of gardeners at the Blackacre and Limerick Community Gardens.

\begin{tabular}{|c|c|c|c|c|c|c|}
\hline & \multicolumn{6}{|c|}{ Years of Gardening Experience } \\
\hline & \begin{tabular}{|c|} 
No \\
Response
\end{tabular} & $\begin{array}{c}\text { Less than } \\
1 \text { year }\end{array}$ & $\begin{array}{c}1-3 \\
\text { years }\end{array}$ & \begin{tabular}{|c|}
$4-10$ \\
years
\end{tabular} & $\begin{array}{c}10-15 \\
\text { years }\end{array}$ & $\begin{array}{c}\text { Over } 15 \\
\text { years }\end{array}$ \\
\hline \multicolumn{7}{|l|}{ Age of Blackacre Females } \\
\hline \multicolumn{7}{|l|}{ Under 20} \\
\hline \multicolumn{7}{|l|}{$21-30$} \\
\hline $31-45$ & & & & $1(3 \%)$ & $1(3 \%)$ & \\
\hline $46-60$ & & & $1(3 \%)$ & $2(6.1 \%)$ & & $1(3 \%)$ \\
\hline 61 or older & & & & & $3(9.1 \%)$ & $4(12.1 \%)$ \\
\hline \multicolumn{7}{|l|}{ Age of Blackacre Males } \\
\hline \multicolumn{7}{|l|}{ Under 20} \\
\hline \multicolumn{7}{|l|}{$21-30$} \\
\hline $31-45$ & & & & $1(3 \%)$ & & \\
\hline $46-60$ & & & $1(3 \%)$ & & $1(3 \%)$ & $2(6.1 \%)$ \\
\hline 61 or older & & & & $3(9.1 \%)$ & $1(3 \%)$ & $\begin{array}{c}11 \\
(33.3 \%)\end{array}$ \\
\hline Total Blackacre Gardeners & & & $\begin{array}{c}2 \\
(6.1 \%) \\
\end{array}$ & $\begin{array}{c}7 \\
(21.2 \%)\end{array}$ & $\begin{array}{c}6 \\
(18.2 \%)\end{array}$ & $\begin{array}{c}18 \\
(54.5 \%)\end{array}$ \\
\hline \multicolumn{7}{|l|}{ Age of Limerick Females } \\
\hline \multicolumn{7}{|l|}{ Under 20} \\
\hline \multicolumn{7}{|l|}{$21-30$} \\
\hline $31-45$ & & $1(6.3 \%)$ & & $1(6.3 \%)$ & & \\
\hline $46-60$ & & & & & & $1(6.3 \%)$ \\
\hline 61 or older & $1(6.3 \%)$ & & & & & $5(31.3 \%)$ \\
\hline \multicolumn{7}{|l|}{ Age of Limerick Males } \\
\hline \multicolumn{7}{|l|}{ Under 20} \\
\hline $21-30$ & & & & $1(6.3 \%)$ & & \\
\hline $31-45$ & & & & $1(6.3 \%)$ & & \\
\hline $46-60$ & & & & & $1(6.3 \%)$ & \\
\hline 61 or older & & & $1(6.3 \%)$ & & & $3(18.8 \%)$ \\
\hline Total Limerick Gardeners & $1(6.3 \%)$ & $1(6.3 \%)$ & $1(6.3 \%)$ & $3(18.8 \%)$ & $1(6.3 \%)$ & $9(56.3 \%)$ \\
\hline
\end{tabular}

Note: Percentages represent percentage of total gardeners at the Blackacre garden or the Limerick garden.

Table 4 contains data representing the number of years gardeners have gardened at their particular community garden. The majority of gardeners at the Limerick garden, eight $(50 \%)$, have gardened there more than three years. The majority of gardeners at the Blackacre garden, 
$16(48.5 \%)$, have gardened there for three years. Ten of the Blackacre gardeners said they had gardened at Blackacre more than three years. This response is inconsistent with the amount of time that the Blackacre Community Garden has actually existed, which is three years. The researcher attributes this discrepancy to the fact that, according to the Blackacre Garden manager, many of the gardeners moved from the LaGrange Road Community Garden to the Blackacre garden once it was established. Those persons who responded they had gardened at the Blackacre garden for more than three years must be taking into account their time at the LaGrange Road Community Garden. Four Blackacre gardeners (12.1\%) and four Limerick gardeners (25\%) responded that this is their first year at their respective community gardens. Table 4: Years of gardening at the Blackacre and Limerick Community Gardens.

\begin{tabular}{|l|c|c|c|c|}
\hline & \multicolumn{2}{|c|}{ Blackacre Gardeners } & \multicolumn{2}{c|}{ Limerick Gardeners } \\
\hline & \# Gardeners & Percentage & \# Gardeners & Percentage \\
\hline No response & 0 & $0.0 \%$ & 0 & $0.0 \%$ \\
\hline This is my first year & 4 & $12.1 \%$ & 4 & $25.0 \%$ \\
\hline 2 Years & 3 & $9.0 \%$ & 2 & $12.5 \%$ \\
\hline 3 years & 16 & $48.5 \%$ & 2 & $12.5 \%$ \\
\hline More than 3 years. & 10 & $30.3 \%$ & 8 & $50.0 \%$ \\
\hline
\end{tabular}

Distance gardeners live from the community garden

The distance gardeners live from their respective community gardens is contained in Table 5. The majority of the Blackacre gardeners surveyed, 27 (81.2\%), live more than five miles away from the garden, while the majority of the Limerick gardeners surveyed, 12 (75\%), live less than one mile from the garden. Only one Limerick gardener reported he lives more than five miles away from the garden; however, the soup kitchen, which receives the garden produce he grows, is near the garden site. 
Table 5: Distance gardeners live from the Blackacre and Limerick Community Gardens.

\begin{tabular}{|l|c|c|c|c|}
\hline & \multicolumn{2}{|c|}{ Blackacre Gardeners } & \multicolumn{2}{c|}{ Limerick Gardeners } \\
\hline & \# Gardeners & Percentage & \# Gardeners & Percentage \\
\hline No response & 0 & $0.0 \%$ & 0 & $0.0 \%$ \\
\hline Less than 1 mile & 2 & $6.1 \%$ & 12 & $75.0 \%$ \\
\hline $1.1-3$ miles & 1 & $3.0 \%$ & 1 & $6.3 \%$ \\
\hline $3.1-5$ miles & 3 & $9.0 \%$ & 1 & $6.3 \%$ \\
\hline More than 5 miles & 27 & $81.2 \%$ & 1 & $6.3 \%$ \\
\hline
\end{tabular}

\section{Time spent in the community gardens}

The amount of time gardeners spend at the Blackacre and Limerick Community Gardens is represented in Table 6. The majority of gardeners at both gardens, 22 of the 33 Blackacre gardeners surveyed (72.8\%) and ten of the 16 Limerick gardeners surveyed (62.5\%), work in the gardens between one and three days a week. The majority of those gardeners, 12 Blackacre gardeners (36.4\%) and eight Limerick gardeners (50\%) spend between one and five hours a week in the gardens. Of the 22 Blackacre gardeners who garden between one and three days a week, eight (24.2\%) spend between six and ten hours a week in the garden and two (6.1\%) spend between 11 and 15 hours a week in the garden. Of the ten Limerick gardeners who spend between one and three days a week in the garden, one gardens between six and ten hours a week and another gardens between 11 and 15 hours a week.

A similar percentage, about 18\%, of Blackacre and Limerick gardeners garden between 11 and 15 hours and 16 hours or more during a week. Of the gardeners who spend 11 hours or more in the gardens, five of the six Blackacre gardeners and two of the three Limerick gardeners are age 61 or older. The other two gardeners are between 46 and 60 years old. 
Table 6: Hours and days per week gardeners spend at the Blackacre and Limerick Community Gardens

\begin{tabular}{|l|c|c|c|c|c|}
\hline & \multicolumn{5}{|c|}{ Hours per week working in the gardens } \\
\hline $\begin{array}{l}\text { Days per week at the } \\
\text { gardens }\end{array}$ & No response & $\mathbf{1 - 5}$ hours & $\mathbf{6 - 1 0}$ hours & $\mathbf{1 1 - 1 5}$ hours & $\begin{array}{c}\mathbf{1 6} \text { hours or } \\
\text { more }\end{array}$ \\
\hline $\begin{array}{c}\text { Blackacre Gardeners } \\
\text { No response }\end{array}$ & & & & & \\
\hline $1-3$ days & $2(6.1 \%)$ & $12(36.4 \%)$ & $8(24.2 \%)$ & $2(6.1 \%)$ & \\
\hline $4-5$ days & & & $4(12.1 \%)$ & $2(6.1 \%)$ & $1(3 \%)$ \\
\hline $\begin{array}{l}\text { 6-7 days } \\
\text { Limerick Gardeners }\end{array}$ & & $1(3 \%)$ & & & $1(3 \%)$ \\
\hline No response & $1(6.3 \%)$ & & & & \\
\hline 1-3 days & & $8(50 \%)$ & $1(6.3 \%)$ & $1(6.3 \%)$ & \\
\hline 4-5 days & & $2(12.5 \%)$ & $1(6.3 \%)$ & & $2(12.5 \%)$ \\
\hline 6-7 days & & & & & \\
\hline
\end{tabular}

Plants grown in the community gardens and uses for those plants

The kinds of plants grown by gardeners is contained in Table 7. The majority of gardeners at both gardens, 20 of the 33 Blackacre gardeners surveyed (60.6\%) and seven of the 16 Limerick gardeners surveyed (43.8\%) grow vegetables only. The next highest category of plants grown by Blackacre gardeners includes vegetables and flowers, grown by five gardeners (15.2\%). Vegetables and flowers were also the next highest category of plants grown among Limerick gardeners, with an equal number of gardeners (2) growing vegetables and herbs.

One Limerick gardener responded that he grows tomatoes, peppers, okra, various herbs, and a blackberry (thornless hybrid) bush, placing him in the category of vegetables, herbs and other. This gardener appears to be one of the few gardeners to grow a perennial plant. 
Table 7: Kinds of plants grown by gardeners at the Blackacre and Limerick Community Gardens.

\begin{tabular}{|l|c|c|c|c|}
\hline & \multicolumn{2}{|c|}{ Blackacre Gardeners } & \multicolumn{2}{c|}{ Limerick Gardeners } \\
\hline & \# Gardeners & Percentage & \# Gardeners & Percentage \\
\hline No response & 2 & $6.1 \%$ & 3 & $18.8 \%$ \\
\hline Vegetables only & 20 & $60.6 \%$ & 7 & $43.8 \%$ \\
\hline Flowers only & 0 & $0.0 \%$ & 0 & $0.0 \%$ \\
\hline Herbs only & 0 & $0.0 \%$ & 0 & $0.0 \%$ \\
\hline Vegetables and Flowers & 5 & $15.2 \%$ & 2 & $12.5 \%$ \\
\hline $\begin{array}{l}\text { Vegetables, Flowers, } \\
\text { and Herbs }\end{array}$ & 0 & $0.0 \%$ & 1 & $6.3 \%$ \\
\hline $\begin{array}{l}\text { Vegetables, Herbs, and } \\
\text { Other * }\end{array}$ & 0 & $0.0 \%$ & 1 & $6.3 \%$ \\
\hline Vegetables and Herbs & 4 & $12.1 \%$ & 2 & $12.5 \%$ \\
\hline Other * & 2 & $6.1 \%$ & 0 & $0.0 \%$ \\
\hline
\end{tabular}

* Note: Two Blackacre survey participants responded in the "other" category. One responded that he grows "all" plants and the other responded that she grows a "variety" of plants. One Limerick gardener's response to this question was best categorized by "vegetables, herbs and other." The "other" kind of plant grown by the gardener is a blackberry bush.

Ways in which the gardeners use the food they grow is represented in Table 8. The majority of gardeners at both gardens, $57.6 \%$ of Blackacre gardeners and $43.8 \%$ of Limerick gardeners, use their food for familial purposes by canning or freezing, giving food to family and friends, and feeding their families. None of the gardeners surveyed uses his or her food for commercial purposes such as selling it at a farmers' market. One of the gardeners uses the food to help support a neighborhood soup kitchen. 
Table 8: Ways gardeners use food grown at the Blackacre and Limerick Community Gardens.

\begin{tabular}{|c|c|c|c|c|}
\hline & \multicolumn{2}{|c|}{ Blackacre Gardeners } & \multicolumn{2}{|c|}{ Limerick Gardeners } \\
\hline & \# Gardeners & Percentage & \# Gardeners & Percentage \\
\hline Can or freeze it only. & 2 & $6.1 \%$ & 1 & $6.3 \%$ \\
\hline $\begin{array}{l}\text { Give it to family and friends } \\
\text { only. }\end{array}$ & 2 & $6.1 \%$ & 2 & $12.5 \%$ \\
\hline $\begin{array}{l}\text { Sell it at a farmers' market } \\
\text { only. }\end{array}$ & 0 & $0.0 \%$ & 0 & $0.0 \%$ \\
\hline Feed my family only. & 2 & $6.1 \%$ & 0 & $0.0 \%$ \\
\hline $\begin{array}{l}\text { Sell it to restaurants and } \\
\text { stores only. }\end{array}$ & 0 & $0.0 \%$ & 0 & $0.0 \%$ \\
\hline Other. & 0 & $0.0 \%$ & $1 *$ & $6.3 \%$ \\
\hline $\begin{array}{l}\text { Can or freeze it, give it to } \\
\text { family and friends, and feed } \\
\text { my family. }\end{array}$ & 19 & $57.6 \%$ & 7 & $43.8 \%$ \\
\hline $\begin{array}{l}\text { Can or freeze it and give it } \\
\text { to family and friends. }\end{array}$ & 4 & $12.1 \%$ & 0 & $0.0 \%$ \\
\hline $\begin{array}{l}\text { Give it to family and friends } \\
\text { and feed my family. }\end{array}$ & 1 & $3.0 \%$ & 3 & $18.8 \%$ \\
\hline $\begin{array}{l}\text { Can or freeze it and feed my } \\
\text { family. }\end{array}$ & 2 & $6.1 \%$ & 0 & $0.0 \%$ \\
\hline $\begin{array}{l}\text { Give it to family and friends } \\
\text { and other. }\end{array}$ & 0 & $0.0 \%$ & $1 *$ & $6.3 \%$ \\
\hline
\end{tabular}

* Note: The percentages do not add up to $100 \%$ because gardeners could choose as many categories as applied to the ways in which they use their food. Two Limerick gardeners use their food for "Other" uses than what was suggested in the survey. One gardener uses the food for a soup kitchen, while the other gardener responded that he gives it to family and friends and in the "Other" category he wrote, "Well, I do use what I can manage."

Reasons for gardening and lessons learned

Table 9 contains the data for responses to the question, "Why do you garden?" The four anticipated categories (Social connections, Health/exercise/therapy, Enjoy working with soil, plants, and nature, and For homegrown/fresh food) were well represented in the gardeners' responses. Of the four anticipated categories, the researcher was surprised to find that "Social connections" did not play more prominently into the gardeners' reasons for gardening. Only five 
Blackacre gardeners (15.2\%) and two Limerick gardeners (12.5\%) cited social connections as reasons for gardening.

Gardening for health/exercise/therapy was mentioned more frequently by Blackacre gardeners than Limerick gardeners. 11 Blackacre gardeners (33.3\%) and one Limerick gardener (6.3\%) responded that gardening was beneficial for their health, a good form of exercise, or a source of therapy.

Ten Blackacre gardeners (30.3\%) and six Limerick gardeners (37.5\%) garden because they enjoy working with soil, plants and nature. About half of the Blackacre gardeners, 17 or $51.5 \%$, garden for the homegrown/fresh food compared with about a third of the Limerick gardeners.

Of the new categories created to meet the gardeners' responses, the category "Hobby/pastime/fun" was well represented by Blackacre gardeners, about half of whom cited this as a reason for gardening compared with three Limerick gardeners (18.8\%). The issue of food security did not play prominently into the gardeners' reasons for gardening. Only one Blackacre gardener and one Limerick gardener claimed to garden in to order to save money. About $12 \%$ of both Blackacre and Limerick gardeners said they garden for a feeling of satisfaction and accomplishment. The remaining two new categories "Connection with the past" and "To help a soup kitchen" were cited by two Limerick gardeners, one for each category.

Table 9: Reasons for gardening given by the Blackacre and Limerick Community Gardeners

\begin{tabular}{|l|c|c|}
\hline & Blackacre Gardeners & Limerick Gardeners \\
\hline Social connections & $5(15.2 \%)$ & $2(12.5 \%)$ \\
\hline For Health/Exercise/Therapy & $11(33.3 \%)$ & $1(6.3 \%)$ \\
\hline Enjoy working with soil, plants and nature & $10(30.3 \%)$ & $6(37.5 \%)$ \\
\hline For home grown/fresh food & $17(51.5 \%)$ & $5(31.3 \%)$ \\
\hline Hobby/pastime/fun & $17(51.5 \%)$ & $3(18.8 \%)$ \\
\hline To save money & $1(3 \%)$ & $1(6.3 \%)$ \\
\hline $\begin{array}{l}\text { For feeling of satisfaction and } \\
\text { accomplishment }\end{array}$ & $4(12.1 \%)$ & $2(12.5 \%)$ \\
\hline Connection with the past & 0 & $1(6.3 \%)$ \\
\hline To help soup kitchen & 0 & $1(6.3 \%)$ \\
\hline No response & $1(3 \%)$ & $2(12.5 \%)$ \\
\hline
\end{tabular}


Note: Percentages do not add up to $100 \%$ because gardeners listed more than one reason for gardening.

While Table 9 deals with gardeners' reasons for gardening, Table 10 contains the data for gardeners' responses to the question, "Why do you garden at the Blackacre or Limerick Community Garden?" This question was designed to elicit the gardeners' reasons for choosing their specific gardening location. The researcher anticipated that accessibility/convenience/ location would be a reason for gardening at the specific garden location; however, she did not expect it to receive the majority of responses, $66.7 \%$ of Blackacre gardeners and $75 \%$ of Limerick gardeners. Given that the majority of Limerick gardeners, $75 \%$, live less than one mile from the garden, it makes sense that accessibility/convenience/location would be important reasons for gardening there. On the other hand, $81 \%$ of Blackacre gardeners live more than five miles from the garden, yet $66.7 \%$ said they garden there for the reason of accessibility/ convenience/location.

The researcher anticipated social connections to figure prominently in the reasons for gardening at the Blackacre and Limerick Community Gardens. Actual responses in this category were surprisingly low, with only four Blackacre gardeners (12.1\%) and one Limerick gardener (6.3\%) citing social connections as reasons for gardening at their garden location. One Blackacre gardener responded, "They (gardeners) are a great group of people to know and work with," while a Limerick gardener stated, “. . . nice to meet other gardeners at Limerick although I haven't had time to be as social as I'd hoped."

Community development was a third category the researcher expected as a reason for gardening at the specific garden location. Responses in this category were surprisingly low as well, with only one gardener from each of the two gardens responding as such. One Blackacre gardener stated that she wanted "to support a community outreach," while one Limerick gardener responded, "It was the novelty at first - gardening in the city. Now it's more a natural provision of those ill-defined yet much discussed designs for urban living. . ." 
In addition to the three categories, (1)Accessibility/convenience/location, (2) Social connections, and (3)Community development, anticipated by the researcher, six new categories were needed to contain the gardeners' responses for gardening at their garden location. These new categories were (1) Security, (2) Limited home garden space, (3) Well-managed garden, (4) Good quality soil, (5) For the vegetables and homegrown items, and (6) Transferred from the LaGrange Road garden.

Security was not a reason for choosing Blackacre because of its location for any of the Blackacre gardeners. Two of the Limerick gardeners specifically stated security as a reason for gardening at the Limerick garden. One Limerick gardener stated she gardened there because, "It's fenced in and only one can get in that have a key." While security was not mentioned by any of the Blackacre gardeners surveyed, it has indeed been an issue this gardening season. Based on information from the Blackacre garden manager, county police have had to patrol the garden at various times this summer after theft of garden produce. Blackacre's openness (no fences, locks, or gates), while inviting, seems to have attracted the wrong kind of attention this season. Limerick, on the other hand, is a fenced-in fortress yielding only to those who have a key, namely gardeners and managers.

Limited home garden space was cited as a reason for gardening at the gardens by four Blackacre gardeners (12.1\%) and three Limerick gardeners (18.8\%). One Blackacre gardener stated she gardens at the Blackacre garden for "convenience - live in an apartment only way I can grow things or garden." The researcher is surprised that limited home garden space did not receive more responses. Because the question was open-ended, the gardeners could respond with any reasons for choosing their specific garden site. Perhaps if the researcher had offered several categories from which to choose, the response would have been higher.

Two Blackacre gardeners cited the good management practices of the Blackacre garden as reasons for gardening there. Three Blackacre gardeners indicated that the quality of Blackacre's soil led them to garden there, while none of the Limerick gardeners gave this as a reason. One Limerick gardener responded that she gardens at the Limerick site because she 
"likes the vegetables and homegrown items." Three Blackacre gardeners responded they garden at Blackacre because they transferred there from the LaGrange Road garden.

Table 10: Reasons for gardening at the Blackacre and Limerick Community Gardens

\begin{tabular}{|l|c|c|}
\hline & Blackacre Gardeners & Limerick Gardeners \\
\hline Accessibility/Convenience/Location & $22(66.7 \%)$ & $12(75 \%)$ \\
\hline Social connections & $4(12.1 \%)$ & $1(6.3 \%)$ \\
\hline Community Development & $1(3 \%)$ & $1(6.3 \%)$ \\
\hline Security & 0 & $2(12.5 \%)$ \\
\hline Limited home garden space & $4(12.1 \%)$ & $3(18.8 \%)$ \\
\hline Well-managed garden & $2(6.1 \%)$ & 0 \\
\hline Good quality soil & $3(9.1 \%)$ & 0 \\
\hline $\begin{array}{l}\text { For the vegetables and homegrown } \\
\text { items }\end{array}$ & 0 & $1(6.3 \%)$ \\
\hline $\begin{array}{l}\text { Transferred from the LaGrange Road } \\
\text { garden } \\
\text { No response }\end{array}$ & $3(9.1 \%)$ & 0 \\
\hline
\end{tabular}

Note: Percentages do not add up to $100 \%$ because gardeners listed more than one reason for gardening.

Table 11 contains the data for responses to the question, "What do you learn from gardening?” Eight Blackacre gardeners (24.2\%) and seven Limerick gardeners (43.8\%) said they learn about self-improvement through gardening. Patience, a sense of accomplishment, the value of hard work, peace, persistence and rewards, commitment, humility, and how to eat better were all listed as lessons learned from gardening.

The majority of gardeners at both gardens, 19 Blackacre gardeners (57.6\%) and 11 Limerick gardeners (68.8\%), said they learn about ecology, reverence for nature, and gardening techniques. Planting techniques, compatibility of plants, weather patterns, the miracle of nature, timing of planting, caring for and harvesting plants, working with the cycles of nature were all lessons learned from gardening.

The third category anticipated by the researcher, caring for community, received a relatively small percentage of responses as lessons learned from gardening. Only five Blackacre gardeners (15.2\%) indicated that caring for community was an important lesson learned from 
gardening, while none of the Limerick gardeners gave this as a reason. Two of the Blackacre gardeners responded they learn about the "generosity of other gardeners" and gain "ideas from others who garden/friendship."

The two new categories, (1) Reverence for God and (2) Greater respect for farmers, accounted for a small number of responses, one response for each category by a Blackacre gardener and a Limerick gardener.

Surprisingly, six Blackacre gardeners (18.2\%) and two Limerick gardeners (12.5\%) did not answer the question, "What do you learn from gardening?" The researcher does not know how to account for this lack of response other than to wonder if there would have been a greater response had the question been followed by a variety of categories to choose from rather than being open-ended.

Table 11: What gardeners learn from gardening

\begin{tabular}{|l|c|c|}
\hline & Blackacre Gardeners & Limerick Gardeners \\
\hline Self-Improvement & $8(24.2 \%)$ & $7(43.8 \%)$ \\
\hline $\begin{array}{l}\text { Ecology, Reverence for Nature, } \\
\text { Gardening Techniques }\end{array}$ & $19(57.6 \%)$ & $11(68.8 \%)$ \\
\hline Caring for community & $5(15.2 \%)$ & 0 \\
\hline Reverence for God & $1(3 \%)$ & $1(6.3 \%)$ \\
\hline Greater respect for farmers & $1(3 \%)$ & $1(6.3 \%)$ \\
\hline No response & $6(18.2 \%)$ & $2(12.5 \%)$ \\
\hline
\end{tabular}

Note: Percentages do not add up to $100 \%$ because gardeners listed more than one lesson learned from gardening.

\section{Community Gardener Survey - Part II}

The following results are based on responses to the Community Gardener Survey, Part II as completed by the Blackacre and Limerick community gardeners who participated in the study. The importance of the quality-of-life statements in relation to the gardening experience

The responses to the quality of life statements as they relate to gardening are found in Table 12. The gardeners rated the importance of each statement as it related to themselves and their gardening experience from one "not important" to five "extremely important." 
Physiological needs. Overall, the Limerick gardeners rated the physiological statements more important than the Blackacre gardeners. In four of the seven physiological statements, specifically those dealing with "enjoying working outside" (statement 2), "the garden colors, smells, beauty" (statement 4), "working with nature" (statement 5), "and working with my hands" (statement 6), the mean for the Limerick gardeners was higher than that for the Blackacre gardeners. In addition, the mode, or the response given most frequently by the gardeners, was higher in four of the seven physiological statements (statement 1-5) for the Limerick gardeners than the Blackacre gardeners. Of those four statements in which the Limerick gardeners' mode was higher than the Blackacre gardeners, three of the four most frequent responses were five (statements 1,2, and 5), indicating that the physiological aspects of gardening are "extremely important" to the Limerick gardeners. The most frequent response given by the Blackacre gardeners for those same statements (statements 1,2, and 5) however, was four, indicating that the physiological aspects of gardening are "very important" to Blackacre gardeners as well.

While the Limerick gardeners' most frequent responses rated higher than the Blackacre gardeners overall for the physiological statements, Blackacre gardeners' most frequent responses also showed that the gardeners value the physiological aspects of gardening. The statements dealing with "working with my hands" and "feeling healthier when I eat my own produce" rated as "extremely important" for the Blackacre gardeners and "very important" and "important" for the Limerick gardeners respectively.

One statement dealing with "needing the physical exercise" rated as a five or "extremely important" for both the Blackacre and Limerick community gardeners. As the majority of the gardeners surveyed are age 61 or older, it is not surprising that this statement rated high for both sets of gardeners. It appears that the gardeners who are age 61 or older find a needed form of exercise and mobility through their gardening.

The findings for the physiological statements are in disagreement with the research of Waliczek, Mattson and Zajicek (1996) who postulated that urban community gardeners would value the physiological aspects of gardening more than more rural gardeners because gardens 
located in urban areas, which may lack in green spaces compared with rural areas, may provide additional opportunities to work with nature. The findings in this study indicate that while the Limerick gardeners, or urban gardeners, do rate higher for their most frequent responses given, the Blackacre gardeners, or suburban gardeners, also value the physiological aspects of gardening, ranking them as "extremely important" or "very important" for six of the seven physiological statements.

Safe environment needs. Limerick gardeners appear to value "feeling safe" (statement 8) in the garden more than the Blackacre gardeners. Both the mean and the mode for the safety statement were higher for the Limerick gardeners than the Blackacre gardeners. The most frequent response given for the safety statement was five, meaning "extremely important," for the Limerick gardeners and three for the Blackacre gardeners, meaning "important." The most apparent reason for the higher safety rating by the Limerick gardeners is the chained link fence which encloses the garden and remains locked at all times. Two of the Limerick gardeners specifically mentioned this security as the reason for gardening at the Limerick Community Garden. In response to the question, "Why do you garden at the Limerick Community Garden?" one Limerick gardener stated, "Because it's fenced in and only one can get in that have a key," while another Limerick gardener stated, "Close to our [soup] kitchen and it's secure." (brackets mine)

Social needs. Blackacre gardeners rated the social needs slightly higher than the Limerick gardeners overall for both the mean and mode. The mean for the Blackacre gardeners' responses showed higher ratings in four of the seven social needs statements, specifically those concerning "good place to meet people" (statement 9), "helping others to garden" (statement 10), "gardening experience helps others" (statement 13), and "caring for my garden and community" (statement 14). The most frequent response given by Blackacre gardeners was higher than Limerick gardeners in three of the seven social needs statements (statements 10,13, and 14), with an additional two statements (statements 9 and 11) having a mode of three or "important" for both Blackacre and Limerick gardeners. 
While the most frequent response was higher overall for the Blackacre gardeners than the Limerick gardeners in the social needs category, it did not rate as high as the mode for the physiological statements whose value was "extremely important" to the Limerick gardeners in four of the seven statements. Only one of the social needs statements rated a five, meaning "extremely important," as the most frequent response by Blackacre gardeners. That statement, (10) "I enjoy helping others to garden," had an equal number of responses whose value was three, indicating it is "important" to the Blackacre gardeners.

Limerick gardeners rated higher for the most frequent response in two of the seven social needs statements. Statement 12 , "I can share my produce with others," rated a four or "very important" as the most frequent response among Limerick gardeners compared with a three or "important" for Blackacre gardeners. Statement 15, "I enjoy working alone," rated a five or "extremely important" as the most frequent response among Limerick gardeners as compared with a three or "important" for Blackacre gardeners.

That Blackacre appears to value the social aspect of gardening more than the Limerick gardeners is not surprising based on the researcher's involvement with the gardens. During the researcher's visits to the Blackacre Community Garden, generally three to five gardeners would be visiting with the garden manager and planning to make lunch together or just visit in the garden manager's trailer. The management of Blackacre seems to promote an extended stay at the garden, often for social purposes. While both the Limerick and Blackacre gardens have picnic tables, only the Blackacre garden has a garden manager's trailer on site equipped with refrigerator, microwave, tables and chairs, etc., lending itself to be a social meeting place.

Self-esteem needs. Limerick gardeners rated the self-esteem needs statements higher than Blackacre gardeners for both the mean and the mode. The Limerick gardeners rated five out of the seven statements higher than Blackacre gardeners for the mean, specifically, those statements dealing with "production of one's own food" (statement 16), "gardening makes me feel good about my own abilities" (statement 18), "being proud of one's garden" (statement 20), "being able to handle the work needed" (statement 21), and "being able to save money" (statement 21). 
Limerick gardeners rated four out of the seven statements higher than Blackacre gardeners for the mode as well and rated them as either "extremely important"(a five), "ery important"(a four), or "mportant"(a three), specifically statements 16, 18, 20 and 22.

While the Limerick gardeners' means and modes were higher than Blackacre gardeners for the self-esteem needs statements, the modes for both groups of gardeners indicate that these needs range from "important" to "extremely important," with all of the most frequent responses being three, four, or five.

Self-actualization needs. Of the two self-actualization needs statements, the more important appears to be statement 23, "My garden gives me a feeling of peace." The average response for both the Blackacre and Limerick gardeners indicated this statement was "very important," compared with the average response for statement 24 "I can teach my children and family to garden," which received an average of 2.59 for Blackacre gardeners and 2.23 for Limerick gardeners, indicating it is "somewhat important."

Food security needs. The gardeners indicated that food security is not an important issue related to gardening. The most frequent response to the food security statement, "I garden because I need the food to live on," was a one, meaning "not important," for both the Blackacre and Limerick gardeners. The average response was only slightly higher for both sets of gardeners and remained in the range of "not important" to "somewhat important."

While the majority of gardeners did not cite food security as being very important, some did. One Blackacre gardener responded to the food security statement with a five, meaning "extremely important," and six Blackacre gardeners responded with a three or four, meaning "somewhat or very important." One Limerick gardener also responded to the food security statement with a five, and two others responded with a three or four. 
Table 12: Means and modes for quality of life statements for all gardeners surveyed at the Blackacre and Limerick Community Gardens.

\begin{tabular}{|c|c|c|c|c|}
\hline & Blackacre & Limerick & Blackacre & Limerick \\
\hline & \begin{tabular}{|c} 
All \\
Gardeners \\
Mean \\
\end{tabular} & $\begin{array}{c}\text { All } \\
\text { Gardeners } \\
\text { Mean } \\
\end{array}$ & Mode & Mode \\
\hline \multicolumn{5}{|l|}{ Physiological } \\
\hline 1. I like to work in the soil. & 3.81 & 3.67 & 4 & 5 \\
\hline 2. I enjoy working outside. & 4.28 & 4.31 & 4 & 5 \\
\hline 3. I need the physical exercise. & 4.32 & 4.27 & 5 & 5 \\
\hline 4. I like the garden colors, smells, beauty. & 3.81 & 4 & 3 & 4 \\
\hline 5. Gardening is working with nature. & 3.94 & 4.13 & 4 & 5 \\
\hline 6. I like to work with my hands. & 4.19 & 4.13 & 5 & 4 \\
\hline 7. I feel healthier when I eat my own produce. & 4.24 & 3.67 & 5 & 3 \\
\hline \multicolumn{5}{|l|}{ Safety } \\
\hline 8. I feel safe in the garden. & 3.42 & 3.87 & 3 & 5 \\
\hline \multicolumn{5}{|l|}{ Social } \\
\hline 9. It's a good place to meet people. & 3.69 & 3.2 & 3 & 3 \\
\hline 10. I enjoy helping others to garden. & 3.58 & 3.07 & 3,5 & 3 \\
\hline 11. The garden beautifies my neighborhood. & 3.03 & 3.64 & 3 & 3 \\
\hline 12. I can share my produce with others. & 3.75 & 4 & 3 & 4 \\
\hline 13. My gardening experience helps others. & 3.38 & 2.93 & 3 & 2 \\
\hline 14. I care for my garden and community. & 3.78 & 3.69 & 4 & 3 \\
\hline 15. I enjoy working alone. & 3.1 & 3.75 & 3 & 5 \\
\hline \multicolumn{5}{|l|}{ Esteem } \\
\hline 16. I can produce my own food. & 3.52 & 3.69 & 3 & 4,5 \\
\hline 17. I can create something of beauty. & 3.75 & 3.69 & 4 & 3 \\
\hline $\begin{array}{l}\text { 18. Gardening makes me feel good } \\
\text { about my own abilities. }\end{array}$ & 3.94 & 4.31 & 4 & 5 \\
\hline $\begin{array}{l}\text { 19. My garden food tastes better } \\
\text { than store-bought food. }\end{array}$ & 4.29 & 4.2 & 5 & 4 \\
\hline 20. Im proud of my garden. & 4 & 4.38 & 4 & 5 \\
\hline 21. I can handle the work needed. & 3.72 & 4 & 4 & 4 \\
\hline 22. I can save money by gardening. & 2.83 & 3.14 & 3 & 3,5 \\
\hline \multicolumn{5}{|l|}{ Self-actualization } \\
\hline 23. My garden gives me a feeling of peace. & 3.61 & 4.07 & 3,4 & 4,5 \\
\hline 24. I can teach my children and family to garden. & 2.59 & 2.23 & 1 & 2 \\
\hline \multicolumn{5}{|l|}{ Food Security } \\
\hline 25. I garden because I need the food to live on. & 1.65 & 1.81 & 1 & 1 \\
\hline
\end{tabular}




\section{DISCUSSION}

\section{Conclusions}

\section{Management of the Blackacre and Limerick Community Gardens}

Two different garden models and perceptions of gardening organizations

The Blackacre and Limerick Community Gardens represent two fairly different community garden models. On the one hand, Blackacre has more of a top-down approach, with management coming from the county government and responsibilities filtering down to the gardeners. On the other hand, Limerick has more of a bottom-up approach, more of a grassroots effort, with the driving force coming from the neighborhood gardeners and support coming from the City of Louisville and the Department of Neighborhoods.

The results of the Garden Manager and County/City Administrator Survey, Part II showed marked differences between the views of the garden manager and administrator for each garden. While the garden managers' and administrators' differing perceptions could be construed as showing a lack of unity within the organization about the organization's goals and work, the researcher suggests other reasons for the finding. The Blackacre garden manager's and administrator's responses are more aligned with one another than the Limerick garden manager's and administrator's responses. The Blackacre garden manager and the two garden administrators are in paid positions which require them to attend meetings, coordinate with other organizations, and be involved with the day to day operations of the organizations which oversee the gardening programs. The Blackacre garden manager and the paid administrators would be in better positions to know the total scope of the work the gardening organization does, while the Limerick garden manager, a volunteer, may not be aware of the other community outreach programs run by the City of Louisville's Department of Neighborhoods. The Limerick garden manager's primary responsibility is management of her garden site and her involvement with the work of the Department of Neighborhoods is likely to be much less than the Blackacre garden manager's involvement with the county's Office of Community Outreach and the administrators' involvement with the two gardening organizations. 
Another possible reason for the differences is a fallacy in the questions. All of the questions ask, "Does your organization ..." without specifying the name of the organization or providing a space to write in the name of the organization. Perhaps if space had been allotted for writing in the name of the gardening organization, the managers and administrators would have written different names. The Limerick garden manager may have been answering the questions from the perspective that the "organization" to which the questions referred was the Limerick garden itself, whereas the Limerick garden administrator appears to have answered the questions from the perspective that the word "organization" in the questions meant the Department of Neighborhoods. This difference in perception could explain why the Limerick garden manager (who answered affirmatively in four planning categories) and the Limerick garden administrator (who responded affirmatively in all ten planning categories) have such differing opinions about the work their gardening organization does.

The responses of the city garden manager and administrator to Question 13 ("Do the organization's gardeners have a say in the organization's direction?") on the Garden Manager and County/City Administrator Survey, Part II serve to illustrate the difference in perception of what is meant by the word "organization" in the questions. The Limerick garden manager responded "yes" to the question, while the Limerick garden administrator responded "no". The researcher concluded that the Limerick garden manager was thinking of the organization as the community garden itself in which case the gardeners do have a say in such matters as when group work days will occur or when to have garden celebrations, etc.

\section{Community garden security}

It appears the city and county government's gardening programs and land use policies do not provide garden security for their community gardens. This is evidenced by the sale of the land on which the LaGrange Road community garden was originally located. Of the county's four community gardens, two are on land owned by the county and two are on land leased from organizations. With regard to the city community gardening program, the security issue is evidenced by the fact that two of the five city-sponsored community gardens are located on 
city-owned land and at least one of those two, the Emerson Community Garden, is on land which the city has already said will be developed some day. It is not known when or if the gardens will face pressure to close because of other, perhaps more profitable, land uses.

The Emerson gardeners, now in their second year of gardening with plans to expand the garden, have been informed by the city that the land could be developed at any time. As the Emerson garden matures and the gardeners become more invested in the garden site, the prospect of having to give up the site will become more difficult.

The Blackacre garden is on prime land for development. The Blackacre State Nature Preserve is somewhat of an anomaly in that it is on land protected from development in an area being rapidly developed. Most recently, a new subdivision, "The Woods at Fox Creek" (where incidentally there is no Fox Creek) has sprung up on the southern border of the nature preserve and an industrial park is only about one mile away to the north. With continued support from the Blackacre Foundation and county government to continue leasing the land, the garden could be preserved indefinitely.

It would be wise for the city and county community gardeners to be aware of the land use issues affecting their gardens and be prepared for either an eventual closing or a political battle to preserve their site. In addition to contacting the community gardening organizations themselves for land use information, the following resources (from Kirschbaum, 2000) could provide help to persons interested in learning how to research land use policy in their community and how to effect change:

- Community Food Security Coalition, Andy Fisher, Director, P.O. Box 209, Venice, CA 90294; website: www.foodsecurity.org

- Madison Advisory Committee on Community Gardens, John Bell, Chair, Madison, WI; Phone: 608-221-6310

- NeighborSpace, 220 S. State St., Suite 1880, Chicago, IL 60604 
- National Neighborhood Coalition, Betty Weiss, Executive Director, 1875

Connecticut Ave. NW, Suite 410, Washington, D.C. 20009; website: www.neighborhoodcoalition.org

- Parks \& People Foundation, Chris Steele, Coordinator of Urban Resources Initiative, 2600 Madison Ave., Baltimore, MD 21217; Phone: 410-396-0730

- Jane E. Schukoske, Associate Professor, Director of the Community Development Clinic, University of Baltimore School of Law, 1420 N. Charles St., Baltimore, MD 21201

- Trust for Public Land, Andrew Stone, Director, New York City Land Project, 666 Broadway, New York, NY 10012; Phone: 212-677-7171

\section{Gardener demographics}

The researcher was surprised to find that the demographics of the gardeners surveyed were more similar than different. The census tract information (see Purpose section of Introduction to study) led the researcher to anticipate that the gardener demographics would be as diverse as the demographics of the census tracts in which the gardens are located. The following statistics show how the census tracts in which the suburban, Blackacre garden and the inner-city, Limerick garden contrast:

- average income $(\$ 19,701$ as of 1990 for inner-city tract on which Limerick garden is located and $\$ 52,266$ for suburban tract on which Blackacre located),

- percentage of residents who own versus rent (renters account for $87 \%$ in the inner-city tract, and $11 \%$ in the suburban tract),

- population density (zero to fifty persons per acre in the inner-city tract and zero to one persons per acre in the suburban tract)

- diversity (inner-city tract is $58 \%$ white, $40 \%$ black, and other, while suburban tract is $98 \%$ white).

While the census tract demographics show two very different sets of population profiles, the gardeners who participated in the study are quite homogenous in terms of race, age, years of 
gardening experience, primary reason for choosing their garden location, and even motivations for gardening and uses for garden produce. The researcher found that 47 of the 49 gardeners who participated in the study categorized themselves as white, while two gardeners, one at each of the gardens, categorized themselves as African-American. The majority of the gardeners surveyed at each site, $66.7 \%$ of Blackacre gardeners and $62.5 \%$ of Limerick gardeners, are age 61 or older. The majority of gardeners at both sites are very experienced gardeners, with over 15 years of gardening experience for $54.5 \%$ of Blackacre gardeners and $56.3 \%$ of Limerick gardeners. Of those gardeners with over 15 years of gardening experience, the majority of them are age 61 or older.

The survey participants appear to be committed to their gardens. The majority of gardeners at both sites have gardened at their site three years or more. $50 \%$ of Limerick gardeners surveyed have gardened there more than three years, while $78.8 \%$ of Blackacre gardeners surveyed have gardened at Blackacre for three years. The Limerick garden is 14 years old while the Blackacre garden is three years old.

The researcher's hunch that the urban community gardeners would live closer to the garden site than the rural/suburban gardeners lived to their site was shown to be correct; however, that finding did not correlate with the gardeners' reasons for choosing their garden location. The majority of Blackacre gardeners surveyed, $81.2 \%$, live more than five miles from the garden, while the majority of Limerick gardeners surveyed, $75 \%$, live less than one mile from the garden. The researcher anticipated that accessibility/ convenience/location would be key reasons for the inner-city gardeners to choose the Limerick garden since they live nearby, however, she did not anticipate the reasons would be the same for the Blackacre gardeners (most of whom live more than five miles away from the site). $66.7 \%$ of Blackacre gardeners and $75 \%$ of Limerick gardeners responded to the open-ended question, "Why do you garden at the Blackacre or Limerick Community Garden?" with answers that fit into the category accessibility/convenience/location. 
The researcher explains the high response of "accessibility/convenience/location" as a reason for gardening at the Blackacre garden by pointing to the major thoroughfares near Blackacre. The Gene Snyder Freeway and Taylorsville Road are both less than one mile from the Blackacre garden, affording easy access to the site. In addition, the Blackacre garden is located in a somewhat rural area of eastern Jefferson County, where sidewalks are rare and the automobile is necessary for transportation. For most Blackacre gardeners, who drive to the garden, easy access is an advantage.

The majority of gardeners at both gardens, $72.8 \%$ of Blackacre gardeners and $62.5 \%$ of Limerick gardeners, work between one and three days a week in the gardens. The majority of these gardeners, $36.4 \%$ of Blackacre gardeners and $50 \%$ of Limerick gardeners, spend between one and five hours a week in the gardens. The researcher anticipated that the gardeners would spend more time in the gardens than their responses indicated.

The majority of gardeners at both gardens, $60.6 \%$ of Blackacre gardeners and $43.8 \%$ of Limerick gardeners grow vegetables only. Only one of the gardeners surveyed, a Limerick gardener, grows a perennial plant. It appears that management of the Blackacre gardens would make growing perennial plants difficult as the land is tilled up in the fall and spring, prohibiting the growth of perennials. On the other hand, the Limerick garden contains beds of perennial flowers and blackberries, showing a difference in soil management which would permit growth of perennials.

The majority of gardeners at both gardens, $57.6 \%$ of Blackacre gardeners and $43.8 \%$ of Limerick gardeners, use the produce they grow for the same purposes, which includes canning or freezing, giving food to family and friends, and feeding their families. None of the gardeners surveyed uses the produce for commercial purposes such as selling at farmers' markets or to restaurants or other outlets. This finding is not too surprising given that the garden managers and administrators for both sites said their organizations do not teach gardeners or encourage them to produce products for sale in stores, at farmers' markets, at restaurants, or through other outlets. 


\section{Motivations for Gardening}

A look at both the responses to the open-ended questions on part I of the Community Gardener Survey and the ratings of the quality-of-life statements on part II of the Community Gardener Survey is necessary to understand the Blackacre and Limerick gardeners' motivations for gardening. For example, without the results of the quality-of-life statements survey, the researcher would have concluded that gardening for physical exercise was not that important to the majority of gardeners surveyed. One Limerick gardener and one-third of Blackacre gardeners responded to the open-ended question, "Why do you garden?" with answers including the words "health," "exercise," and "therapy." The quality-of-life statements, however, indicated that "needing the physical exercise" is an important reason for gardening for a majority of the Blackacre and Limerick gardeners (see table 13). $51.6 \%$ of Blackacre gardeners and $53.3 \%$ of Limerick gardeners rated the statement "I need the physical exercise" "extremely important." $29 \%$ of Blackacre gardeners and $26.7 \%$ of Limerick gardeners rated the statement "very important" and 19.4\% of Blackacre gardeners and 13.3\% of Limerick gardeners rated the statement "important." None of the gardeners rated the statement, "I need the physical exercise" "unimportant" and only one gardener rated it "somewhat important."

Table 13: Comparison of responses to the open-ended question, "Why do you garden?" with responses to quality-of-life statement (\#3) for physical exercise.

\begin{tabular}{|c|c|c|c|c|c|}
\hline & \multicolumn{5}{|c|}{ Open-ended question, "Why do you garden?" } \\
\hline & \multicolumn{5}{|c|}{ For health/exercise/therapy } \\
\hline Blackacre & \multicolumn{5}{|c|}{$33.3 \%$} \\
\hline \multirow[t]{3}{*}{ Limerick } & \multicolumn{5}{|c|}{$6.3 \%$} \\
\hline & \multicolumn{5}{|c|}{ Quality-of-life statement, "I need the physical exercise." } \\
\hline & Not Important & $\begin{array}{l}\text { Somewhat } \\
\text { important }\end{array}$ & Important & Very important & $\begin{array}{l}\text { Extremely } \\
\text { important }\end{array}$ \\
\hline Blackacre & $0 \%$ & $0 \%$ & $19.4 \%$ & $29.0 \%$ & $51.6 \%$ \\
\hline Limerick & $0 \%$ & $6.7 \%$ & $13.3 \%$ & $26.7 \%$ & $53.3 \%$ \\
\hline
\end{tabular}

Having both open-ended questions and categorical statements provides a better overall understanding of the gardeners and their motivations for gardening. 


\section{Physiological aspects of gardening}

In response to the open-ended question, "Why do you garden?," both the Blackacre and Limerick gardeners indicated they value the physiological aspects of gardening. $30.3 \%$ of Blackacre gardeners and $37.5 \%$ of Limerick gardeners enjoy working with soil, plants, and nature. $51.5 \%$ of Blackacre gardeners and $31.3 \%$ of Limerick gardeners value gardening for the homegrown and fresh food. $51.5 \%$ of Blackacre gardeners and $18.8 \%$ of Limerick gardeners responded they value gardening as a hobby/pastime/fun.

This sentiment, enjoying the physiological aspects of gardening, is echoed in the findings of the quality-of-life statements, "I enjoy working outside" and "I like to work in the soil" (See table 14). Working outside is an important reason for gardening for a majority of the Blackacre and Limerick gardeners. For $40.6 \%$ of Blackacre gardeners and $62.5 \%$ of Limerick gardeners, the statement, "I enjoy working outside" was rated "extremely important." For $46.9 \%$ of Blackacre gardeners and $6.3 \%$ of Limerick gardeners, the statement was "very important." For $12.5 \%$ of Blackacre gardeners and $31.3 \%$ of Limerick gardeners, the statement was "important." None of the gardeners indicated that working outside is unimportant. Working in the soil is an important reason for gardening for a majority of the Blackacre and Limerick gardeners. For $21.9 \%$ of Blackacre gardeners and $37.5 \%$ of Limerick gardeners, the statement, "I like to work in the soil" was rated "extremely important." For $43.8 \%$ of Blackacre gardeners and $18.8 \%$ of Limerick gardeners, the statement was rated "very important" and for $31.3 \%$ of Blackacre gardeners and $25 \%$ of Limerick gardeners, the statement was rated "important." Only one Blackacre gardener rated the statement "I like to work in the soil" "unimportant" and two Limerick gardeners rated the statement "somewhat important." Blackacre and Limerick gardeners enjoy working outside and value it as important, very important, or extremely important. 
Table 14: Comparison of responses to the open-ended question, "Why do you garden?" with responses to quality-of-life statements $(\# 1,2)$ for physiological aspects of gardening.

\begin{tabular}{|c|c|c|c|c|c|}
\hline & \multicolumn{5}{|c|}{ Open-ended question, "Why do you garden?" } \\
\hline & \multicolumn{2}{|c|}{ Enjoy working with soil, plants, nature } & \multicolumn{2}{|c|}{ For homegrown/fresh food } & Hobby/pastime/fun \\
\hline Blackacre & \multicolumn{2}{|c|}{$30.3 \%$} & \multicolumn{2}{|c|}{$51.5 \%$} & $51.5 \%$ \\
\hline \multirow[t]{3}{*}{ Limerick } & & & & & $18.8 \%$ \\
\hline & \multicolumn{5}{|c|}{ Quality-of-life statement, "I enjoy working outside." } \\
\hline & Not important & $\begin{array}{l}\text { Somewhat } \\
\text { important }\end{array}$ & Important & Very important & Extremely important \\
\hline Blackacre & $0.0 \%$ & $0.0 \%$ & $12.5 \%$ & $46.9 \%$ & $40.6 \%$ \\
\hline \multirow[t]{3}{*}{ Limerick } & $0.0 \%$ & $0.0 \%$ & $31.3 \%$ & $6.3 \%$ & $62.5 \%$ \\
\hline & \multicolumn{5}{|c|}{ Quality-of-life statement, "I like to work in the soil." } \\
\hline & Not important & $\begin{array}{l}\text { Somewhat } \\
\text { important }\end{array}$ & Important & Very important & Extremely important \\
\hline Blackacre & $3.1 \%$ & $0.0 \%$ & $31.3 \%$ & $43.8 \%$ & $21.9 \%$ \\
\hline Limerick & $0.0 \%$ & $18.8 \%$ & $25.0 \%$ & $18.8 \%$ & $37.5 \%$ \\
\hline
\end{tabular}

Social connections of gardening

Responses to the open-ended question, "Why do you garden?," indicated that the social connections of gardening did not appear to play that significant a role in the gardeners' reasons for gardening, although they were mentioned by $15.2 \%$ of Blackacre gardeners and $12.5 \%$ of Limerick gardeners. A look at the results of the quality-of-life statements survey, however, shows that the social aspects of gardening are important to a majority of gardeners (See table $15)$.

For $28.1 \%$ of Blackacre gardeners and $20 \%$ of Limerick gardeners, the garden is "extremely important" in terms of meeting others. For $29.1 \%$ of Blackacre gardeners and $13.3 \%$ of Limerick gardeners, the garden is "very important" in terms of meeting others, and for $31.3 \%$ of Blackacre gardeners and $40 \%$ of Limerick gardeners, the garden is "important" in terms of meeting others.

Helping others to garden is important to the majority of gardeners. For $29 \%$ of Blackacre gardeners and $20 \%$ of Limerick gardeners, helping others to garden is considered "extremely important." For $22.6 \%$ of Blackacre gardeners and $13.3 \%$ of Limerick gardeners, 
helping others to garden is considered "very important." One Blackacre gardener and two Limerick gardeners indicated helping others to garden was "unimportant."

Sharing produce with others is important to the majority of gardeners. For $21.9 \%$ of Blackacre gardeners and $33.3 \%$ of Limerick gardeners, sharing their produce with others is considered "extremely important." For $34.4 \%$ of Blackacre gardeners and $40 \%$ of Limerick gardeners, sharing produce is "very important." None of the gardeners indicated sharing produce with others is "unimportant."

Table 15: Comparison of responses to open-ended question, "Why do you garden?" with responses to quality-of-life statements $(\# 9,10,12)$ for social connections.

\begin{tabular}{|c|c|c|c|c|c|}
\hline & \multicolumn{5}{|c|}{ Open-ended question, "Why do you garden?" } \\
\hline & \multicolumn{5}{|c|}{ Social connections } \\
\hline Blackacre & \multicolumn{5}{|c|}{$15.2 \%$} \\
\hline \multirow[t]{3}{*}{ Limerick } & \multicolumn{5}{|c|}{$12.5 \%$} \\
\hline & \multicolumn{5}{|c|}{ Quality-of-life statement, "It's a good place to meet people." } \\
\hline & Not important & $\begin{array}{l}\text { Somewhat } \\
\text { important }\end{array}$ & Important & Very important & $\begin{array}{l}\text { Extremely } \\
\text { important }\end{array}$ \\
\hline Blackacre & $3.1 \%$ & $9.4 \%$ & $31.3 \%$ & $28.1 \%$ & $28.1 \%$ \\
\hline \multirow[t]{3}{*}{ Limerick } & $6.7 \%$ & $20.0 \%$ & $40.0 \%$ & $13.3 \%$ & $20.0 \%$ \\
\hline & \multicolumn{5}{|c|}{ Quality-of-life statement, "I enjoy helping others to garden." } \\
\hline & Not important & $\begin{array}{l}\text { Somewhat } \\
\text { important }\end{array}$ & Important & Very important & $\begin{array}{l}\text { Extremely } \\
\text { important }\end{array}$ \\
\hline Blackacre & $3.2 \%$ & $16.1 \%$ & $29.0 \%$ & $22.6 \%$ & $29.0 \%$ \\
\hline \multirow[t]{3}{*}{ Limerick } & $13.3 \%$ & $20.0 \%$ & $33.3 \%$ & $13.3 \%$ & $20.0 \%$ \\
\hline & \multicolumn{5}{|c|}{ Quality-of-life statement, "I can share my produce with others." } \\
\hline & Not important & $\begin{array}{l}\text { Somewhat } \\
\text { important }\end{array}$ & Important & Very important & $\begin{array}{l}\text { Extremely } \\
\text { important }\end{array}$ \\
\hline Blackacre & $0.0 \%$ & $3.1 \%$ & $40.6 \%$ & $34.4 \%$ & $21.9 \%$ \\
\hline Limerick & $0.0 \%$ & $6.7 \%$ & $20.0 \%$ & $40.0 \%$ & $33.3 \%$ \\
\hline
\end{tabular}

\section{Food security}

While food security has been shown by some researchers to be a significant reason for gardening, it does not appear to be the primary motivation for gardeners surveyed at the Blackacre and Limerick community gardens. Only one Blackacre gardener and one Limerick gardener cited this as a reason for gardening in response to the open-ended question, "Why do you garden?" This finding is echoed in the results of quality-of-life statement 25, "I garden because I need to food to live on." Gardening for food security was "unimportant" for $71 \%$ of Blackacre gardeners and $56.3 \%$ of Limerick gardeners. Gardening for food security was 
"somewhat important" for more Limerick gardeners (25\%) than Blackacre gardeners $(6.5 \%)$. Gardening for food security was "extremely important," however, for one gardener at both the Blackacre and the Limerick garden, and "somewhat important" to "very important" for six Blackacre gardeners (18.2\%) and two Limerick gardeners (12.5\%).

Table 16: Comparison of responses to open-ended question, "Why do you garden?" with responses to quality-of-life statement (\#25) for food security.

\begin{tabular}{|c|c|c|c|c|c|}
\hline & \multicolumn{5}{|c|}{ Open-ended question, "Why do you garden?" } \\
\hline & \multicolumn{5}{|c|}{ To save money } \\
\hline Blackacre & \multicolumn{5}{|c|}{$3 \%$} \\
\hline \multirow[t]{3}{*}{ Limerick } & \multicolumn{5}{|c|}{$6.3 \%$} \\
\hline & \multicolumn{5}{|c|}{ Quality-of-life statement, "I garden because I need the food to live on." } \\
\hline & Not important & $\begin{array}{c}\text { Somewhat } \\
\text { important }\end{array}$ & Important & Very important & $\begin{array}{l}\text { Extremely } \\
\text { important }\end{array}$ \\
\hline Blackacre & $71 \%$ & $6.5 \%$ & $12.9 \%$ & $6.5 \%$ & $3.2 \%$ \\
\hline Limerick & $56.3 \%$ & $25.0 \%$ & $6.3 \%$ & $6.3 \%$ & $6.3 \%$ \\
\hline
\end{tabular}

Learning from the gardening experience

Responses to the open-ended question, "What do you learn from gardening?" indicated that self-improvement (gaining a sense of accomplishment, patience, the value of hard work, persistence and rewards, and commitment) was an important lesson learned by $24.2 \%$ of Blackacre gardeners and $43.8 \%$ of Limerick gardeners. It appears that the value of self-improvement is even more important than the open-ended question would have the researcher conclude.

The results of the quality-of-life statement, "I can produce my own food," indicate that production of one's own food is "extremely important" to $29 \%$ of Blackacre gardeners and $31.3 \%$ of Limerick gardeners. Production of one's own food is "very important" for $16.1 \%$ of Blackacre gardeners and $31.3 \%$ of Limerick gardeners and "important" for $38.7 \%$ of Blackacre gardeners and $12.5 \%$ of Limerick gardeners. Only one Blackacre gardener indicated that production of one's own food is "unimportant."

The quality-of-life statement, "Gardening makes me feel good about my own abilities," was rated as important by a majority of gardeners. $25 \%$ of Blackacre gardeners and $50 \%$ of 
Limerick gardeners rated this sentiment at "extremely important," while $43.8 \%$ of Blackacre gardeners and $31.3 \%$ of Limerick gardeners rated it "very important." None of the gardeners indicated that "Gardening makes me feel good about my own abilities" is "unimportant."

A majority of the gardeners value being proud of their garden. $33.3 \%$ of Blackacre gardeners and $50 \%$ of Limerick gardeners rated the quality-of-life statement, "I'm proud of my garden," "extremely important." $40 \%$ of Blackacre gardeners and $37.5 \%$ of Limerick gardeners rated the statement "very important." None of the gardeners felt that being proud of their garden was "unimportant."

Table 17: Comparison of responses to open-ended question, "What do you learn from gardening?" with responses to quality-of-life statements $(\# 16,18,20)$ for self-improvement.

\begin{tabular}{|c|c|c|c|c|c|}
\hline & \multicolumn{5}{|c|}{ Open-ended question, "What do you learn from gardening?" } \\
\hline & \multicolumn{5}{|c|}{ Self-improvement } \\
\hline Blackacre & \multicolumn{5}{|c|}{$24.2 \%$} \\
\hline \multirow[t]{3}{*}{ Limerick } & \multicolumn{5}{|c|}{$43.8 \%$} \\
\hline & \multicolumn{5}{|c|}{ Quality-of-life statement, "I can produce my own food." } \\
\hline & Not important & $\begin{array}{l}\text { Somewhat } \\
\text { important }\end{array}$ & Important & Very important & $\begin{array}{l}\text { Extremely } \\
\text { important }\end{array}$ \\
\hline Blackacre & $6.5 \%$ & $9.7 \%$ & $38.7 \%$ & $16.1 \%$ & $29.0 \%$ \\
\hline \multirow[t]{3}{*}{ Limerick } & $0.0 \%$ & $25.0 \%$ & $12.5 \%$ & $31.3 \%$ & $31.3 \%$ \\
\hline & \multicolumn{5}{|c|}{ Quality-of-life statement, "Gardening makes me feel good about my abilities." } \\
\hline & Not important & $\begin{array}{l}\text { Somewhat } \\
\text { important }\end{array}$ & Important & Very important & $\begin{array}{l}\text { Extremely } \\
\text { important }\end{array}$ \\
\hline Blackacre & $0.0 \%$ & $0.0 \%$ & $31.3 \%$ & $43.8 \%$ & $25.0 \%$ \\
\hline \multirow[t]{3}{*}{ Limerick } & $0.0 \%$ & $0.0 \%$ & $18.8 \%$ & $31.3 \%$ & $50.0 \%$ \\
\hline & \multicolumn{5}{|c|}{ Quality-of-life statement, "I'm proud of my garden." } \\
\hline & Not important & $\begin{array}{l}\text { Somewhat } \\
\text { important }\end{array}$ & Important & Very important & $\begin{array}{l}\text { Extremely } \\
\text { important }\end{array}$ \\
\hline Blackacre & $0.0 \%$ & $6.7 \%$ & $20.0 \%$ & $40.0 \%$ & $33.3 \%$ \\
\hline Limerick & $0.0 \%$ & $0.0 \%$ & $12.5 \%$ & $37.5 \%$ & $50.0 \%$ \\
\hline
\end{tabular}

Caring for community

The researcher anticipated that caring for community would be another lesson learned from gardening, but found that only a small percentage of gardeners, $15.2 \%$ of Blackacre gardeners and no Limerick gardeners, stated caring for community as a lesson learned in response to the open-ended question, "What do you learn from gardening?" A look at the results 
of the quality-of-life statement, "I care for my garden and community," however, shows that caring for community is "extremely important" to $18.8 \%$ of Blackacre gardeners and $25 \%$ of Limerick gardeners. Caring for the garden and community is "very important" to $46.9 \%$ of Blackacre gardeners and $25 \%$ of Limerick gardeners, and is "important" to $28.1 \%$ of Blackacre gardeners and $43.8 \%$ of Limerick gardeners. None of the gardeners indicated that caring for community is "unimportant" based on the quality-of-life statement.

Table 18: Comparison of responses to open-ended question, "What do you learn from gardening?" with responses to quality-of-life statement (\#14) for caring for community.

\begin{tabular}{|c|c|c|c|c|c|}
\hline & \multicolumn{5}{|c|}{ Open-ended question, "What do you learn from gardening? } \\
\hline & \multicolumn{5}{|c|}{ Caring for community } \\
\hline Blackacre & \multicolumn{5}{|c|}{$15.2 \%$} \\
\hline Limerick & \multicolumn{5}{|c|}{$0.0 \%$} \\
\hline & \multicolumn{5}{|c|}{ Quality-of-life statement, "I care for my garden and community." } \\
\hline & Not important & $\begin{array}{l}\text { Somewhat } \\
\text { important }\end{array}$ & Important & Very important & $\begin{array}{l}\text { Extremely } \\
\text { important }\end{array}$ \\
\hline Blackacre & $0.0 \%$ & $6.3 \%$ & $28.1 \%$ & $46.9 \%$ & $18.8 \%$ \\
\hline Limerick & $0.0 \%$ & $6.3 \%$ & $43.8 \%$ & $25.0 \%$ & $25.0 \%$ \\
\hline
\end{tabular}

\section{Summary}

The purpose of this study was to compare the characteristics and motivations of community gardeners at the suburban Blackacre Community Garden and inner-city Limerick Community Garden, as well as to compare management practices, looking for commonalities and differences in the county- and city-managed gardens and gardening organizations. Towards those ends, this study has been useful. At the outset of the study, the researcher anticipated significant differences in gardener characteristics and motivations based on the location of the gardens. The results of this study, however, indicate that the characteristics and motivations of gardeners at the inner-city garden and the suburban garden are more similar than different. Results show that the Blackacre and Limerick community gardens provide many quality-of-life benefits to the community gardeners surveyed. These findings are not meant to be representative of all inner-city and suburban community gardens. It is highly likely that had the researcher chosen other garden sites, the findings might have been different. 
This study has shown that the county- and city-sponsored community gardening organizations in Jefferson County, Kentucky are operated under similar rules and regulations, but have different philosophies in terms of who is responsible for creating a new community garden. The city gardening program leaves the responsibility up to interested citizens, while the county gardening program takes the initiative itself to secure land and start a garden. Both the county- and city-sponsored community gardening organizations fulfill a number of planning-like functions.

\section{Recommendations for Future Research}

This study has shown that community garden security is an issue for the City of Louisville and Jefferson County's community gardens. Research concerning open space policies and land-use issues in Jefferson County as they relate to community gardens and other community uses could be beneficial to the preservation of community gardens. What are the city's official open space policies and how do they relate to community gardens? Are community gardens represented in the comprehensive plan for the city and county?

Further research concerning community gardeners' attitudes towards preserving their community gardens could also be worthwhile. In New York City's Esperanza garden, for example, gardeners and garden supporters rallied and protested the razing of their garden. Are their actions representative of community gardeners' commitment to their gardens nationwide? When the Jefferson County LaGrange Road garden closed because the county sold the land, why didn't the gardeners protest the closing of their 14 year old garden or seek some political remedy?

Community gardens are often touted as being able to build a community's leadership base, organizational skills, and political involvement. Are these benefits realized in Jefferson County, Kentucky's community gardens? Further research could provide a more detailed look at individual gardeners and provide a better understanding of.community gardeners and their civic involvement as a result of their community gardening experience. 


\section{REFERENCES}

Bassett, Thomas J. (1981). Reaping on the Margins, A Century of Community Gardening in America. Landscape, 25(2), 1-8.

Chivers, C.J. (2000, February 16). After Uprooting Gardeners, City Razes a Garden. New York Times.

Francis, Mark, Lisa Cashdan, and Lynn Paxson. (1984). Community Open Spaces: Greening Neighborhoods Through Community Action and Land Conservation. Washington, D.C.: Island Press.

Herbach, Geoffrey. (1998) Community Gardening Organizations' Relationship to the Public Planning Function: A Story of Shared Goals. Master's Thesis. University of WisconsinMadison.

Hynes, Patricia H. (1996). A Patch of Eden, America's Inner-City Gardeners. White River Junction, VT: Chelsea Green Publishing Company.

Kaplan, Rachel and Stephen Kaplan. (1989). The Experience of Nature, A Psychological Perspective. New York: Cambridge University Press.

Kirschbaum, Pamela (2000). Making Policy in a Crowded World: Steps Beyond the Physical Garden. Community Greening Review, 2-11.

Malakoff, David (1995). What Good is Community Greening? Community Greening Review, 4-11.

Punch, Walter T., gen. ed. (1992). Keeping Eden, A History of Gardening in America. Massachusetts Horticultural Society. Boston: Bulfinch Press Book, Little, Brown, and Co., 159-161.

Severson, Rebecca. (1990). United We Sprout: A Chicago Community Garden Story. In Mark Francis and Randolph T. Hester, Jr. (Eds.), The Meaning of Gardens, Idea, Place and Action (pp. 80-85). Cambridge, MA: MIT Press.

SOUL, Save Our Urban Land. Website. http://www.urbanext.uiuc.edu/programs/soul.html Sustainable Food Center. (1996). Growing Together: Community Gardening and Food Security. 
Austin, Texas.

Waliczek, Tina M. Richard H. Mattson, and Jayne M. Zajicek. (1996). Benefits of Community Gardening on Quality of Life Issues. Journal of Environmental Horticulture. 14(4), 204-209.

Winne, Mark, Hugh Joseph, and Andy Fisher. (1996). Community Food Security: A Guide to Concept, Structure, Content, and Implementation. Community Food Security Coalition. 


\title{
APPENDIX A
}

\section{Community Gardener Survey - Part I}

\section{Blackacre Community Garden}

\author{
Limerick Community Garden
}

You are being invited to participate in a research study. The purpose of this study is to compare characteristics and motivations of community gardeners at the Blackacre and Limerick community gardens in Jefferson County, as well as to compare management practices, looking for commonalities and differences in the county and city managed gardens. This study is being conducted by Robin Grossman and is sponsored by the Graduate School, Interdisciplinary Studies Program at the University of Louisville.

Please remember that your participation in this study is voluntary. If you agree to participate, you will fill out the survey, which should take approximately 10 minutes. You may decline to answer any question. There are no risks or benefits to you for participation; however, the knowledge gained may benefit others. Your completed survey will be stored at the Department of Interdisciplinary Studies. Individuals from the Department of Interdisciplinary Studies and the University Human Studies Committee may inspect these records. In all other respects, however, the data will be held in confidence to the extent permitted by law. Should the data be published, your identity will not be disclosed.

By participating in this research, you are indicating that all your present questions have been answered in language you can understand. All future questions will be treated in the same manner. You may refuse to participate. If you have any questions about this study, you may contact the principal investigator at (502)852-0791. If you have any questions about your rights as a research subject, you can contact the University Human Studies Committee at (502)852-5188. The committee has reviewed this study. By responding to the survey questions, you are agreeing to participate.

1. How many years of gardening experience do you have? Less than 1 year __ 1 - 3 years $4-10$ years $10-15$ years over 15 years

2. How long have you gardened at this community garden? This is my first year. 2 years 3 years More than 3 years

3. Gender: Male Female

4. Which category includes your age? Under 20 $21-30$ $31-45$ $46-60$ 61 or older

5. Which category describes your ethnicity? White Asian/Pacific Islander African American Hispanic Other

6. Which category describes your income (for statistical purposes only)?

$\begin{array}{ccc}\$ 0-\$ 10,000 & \$ 10,001-\$ 20,000 & \$ 20,001-\$ 30,000 \\ \$ 30,001-\$ 50,000 & \text { Greater than } \$ 50,000\end{array}$

7. How far do you live from the garden? Less than 1 mile 1.1 - 3 miles 3.1 - 5 miles More than 5 miles 
8. How many days per week do you work in the community garden?

1-3 days 4-5 days 6-7 days

9. How many hours per week do you work in the community garden? 1-5 hours 6-10 hours 11-15 hours 16 hours or more

10. What kinds of plants do you grow?

11. Which of the following describe how you use your food?

Can or freeze it.

Give it to family and friends.

Sell it at a farmers market.

Feed my family.

Sell it to restaurants or stores.

Other:

12. Why do you garden?

13. Why do you garden at the [Blackacre] or [Limerick] Community Garden?

14. What do you learn from gardening? 


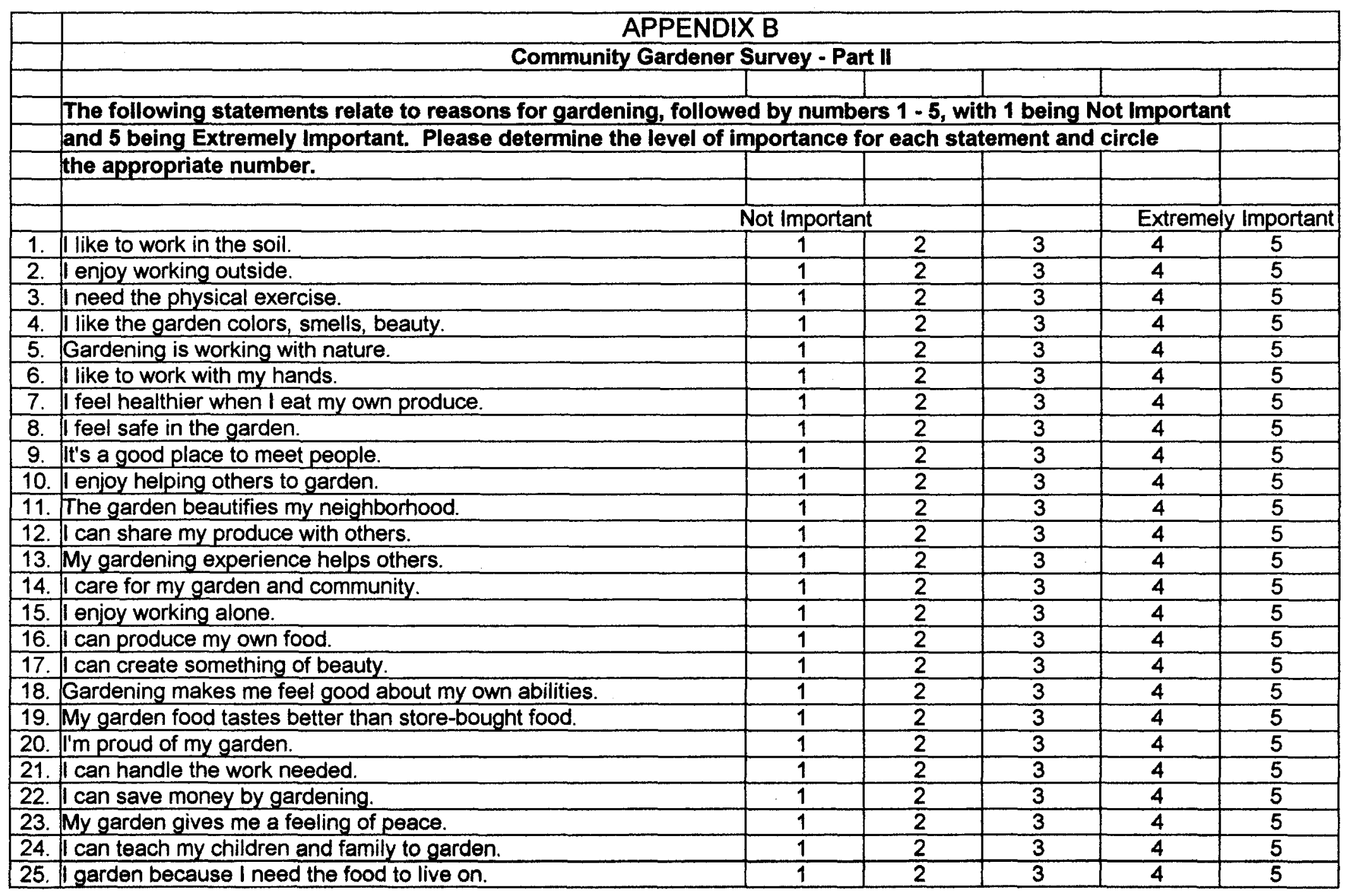




\section{APPENDIX C}

\section{Community Garden Manager \\ And County/City Administrator Survey - Part I}

\section{Blackacre Community Garden}

\section{Limerick Community Garden}

You are being invited to participate in a research study. The purpose of this study is to compare characteristics and motivations of community gardeners at the Blackacre and Limerick community gardens in Jefferson County, as well as to compare management practices, looking for commonalities and differences in the county and city managed gardens. This study is being conducted by Robin Grossman and is sponsored by the Department of Interdisciplinary Studies at the University of Louisville.

Please remember that your participation in this study is voluntary. If you agree to participate, you will respond to the following questions on Parts I and II of the survey. You may decline to answer any question. There are no risks or benefits to you for participation; however, the knowledge gained may benefit others. Your completed survey will be stored at the Department of Interdisciplinary Studies. Individuals from the Department of Interdisciplinary Studies and the University Human Studies Committee may inspect these records. In all other respects, however, the data will be held in confidence to the extent permitted by law. Should the data be published, your identity will not be disclosed.

By participating in this research, you are indicating that all your present questions have been answered in language you can understand. All future questions will be treated in the same manner. You may refuse to participate. If you have any questions about this study, you may contact the principal investigator at (502)852-0791. If you have any questions about your rights as a research subject, you can contact the University Human Studies Committee at (502)852-5188. The committee has reviewed this study. By responding to the survey questions, you are agreeing to participate.

1. When was the garden established?

2. How was the garden started and by whom was it organized?

3. How was it determined there was a need for the garden?

4. How was the location of the garden chosen? 
5. Who owns the land on which the garden is located?

6. What is the size of the garden?

7. Do gardeners have individual plots or are there communal gardening plots? What size are the plots?

8. How many gardeners are at this site?

9. At what age level are the majority of gardeners at your site?

How do you explain this age cluster at your site?

10. What are your roles as [garden manager] [county/city administrator]?

11. Who prepares the land for the new gardening season?

12. What role do gardeners play in planning and developing the site, either the garden as a whole or their individual plots?

13. Is there a fee to garden? If so, how much? 
14. What is the application process for someone who wishes to garden?

15. Are there written rules which must be agreed to? Yes No If yes, what are the consequences for breaking the rules?

16. Does your organization provide the following for the gardeners?

16a. tools?

16b. water?

16c. compost?

16d. other?

16 e. starter vegetables and seeds?

17. Do you have gardening activities, such as celebrations, picnics, friendly competitions? If so, who plans them (gardeners or managers or both)? 


\section{APPENDIX D}

\section{Community Garden Manager \\ And County/City Administrator Survey - Part II}

Please circle the appropriate response to the following questions.

1. Does your organization work to improve the social and physical environments of the neighborhoods in which your gardens are located?

Yes

No

2. Does your organization address urban problems

$\begin{array}{lll}\text { 2a. Joblessness? } & \text { Yes } & \text { No } \\ \text { 2b. Drug abuse? } & \text { Yes } & \text { No } \\ \text { 2c. Vandalism? } & \text { Yes } & \text { No }\end{array}$

2d. Others?

3. Does your organization offer programs that teach gardeners to market products of the gardens in stores, at farmers markets, at restaurants, or through another outlet?

Yes No

4. Does your organization link the development of gardens with the development of
4a. Housing?
Yes
No
4b. Local businesses? Yes
No

5. Does your organization work with schools to run youth educational programs in community or school gardens?

Yes No

6. Does your organization deal with environmental sustainability in any of its programs or in its mission statement?

Yes No

7. Does your organization work on projects in partnership with
7a. Businesses?
Yes
No
7b. Government?
Yes
No
$7 \mathrm{c}$. Non profit organizations? Yes
No

8. Has your organization created a written plan for organizational growth?

Yes

No 
9. Has your organization created a written plan for the development of new gardens and garden related programs based on perceived demographic or economic change occurring in your city?
Yes
No

10. Do you have specific programs meant to work with people affected by welfare reform?

Yes No

11. Does your organization provide access for handicapped gardeners?

Yes No

12. Does your organization do outreach work to minority groups?

Yes No

13. Do the organization's gardeners have a say in the organization's direction?

Yes No

14. Do gardeners have a say in decisions made at their particular garden sites?

Yes

No

15. Is there a plan to develop leadership and organization at individual garden sites?

Yes No

16. Are non-gardening interests in the communities your organization serves involved in the decision making for sites in their (the non-gardening interests') neighborhoods?

Yes

No

17. Does staff and/or students from a local college or university work with your organization?

Yes

No

18. Does county extension staff work with your organization?

Yes No 
The author, Robin Oxnard Grossman, is the daughter of Bobbi Oxnard, the late John Oxnard, and Jerry Bentley, of Ashland, Kentucky. She was born August 11, 1974, in Tyrone, Pennsylvania.

Her primary and secondary education was obtained in the public schools of Ashland, Kentucky, where she graduated in 1992.

In August, 1992, Robin entered the University of Kentucky, and in June, 1997, she received the degree of Bachelor of Arts with honors in the double major of Spanish and Latin American Studies.

From August, 1996 to July, 1998, the author was an AmeriCorps Member with Eastern Kentucky University's Student Service Consortium. She served as a Service-Learning Coordinator in Estill County, Kentucky's public schools.

In August, 1998, Robin entered the University of Louisville to pursue an Interdisciplinary Studies master's degree with concentrations in Environmental Education and Management. This thesis marks the completion of that degree. Robin lives in Louisville, Kentucky with her husband, Eric and son, Gavin. 